\title{
A COMPARISON OF ENERGY INTENSITY IN THE UNITED STATES AND JAPAN
}

S. C. McLonald

December 1990

Prepared for the U.S. Department of Energy under Contract DE-AC06-76RLO 1830

Pacific Northwest Laboratory

Richland, Washington 99352 


\section{ACKNOWLEDGMENTS}

This report was funded by the Carbon Dioxide Research Program within the Office of Energy

Research, U.S. Department of Energy. The author would like to thank Dr. Ari Patrinos and Dr. Fredrick Koomanoff for their support and direction. Thanks are also due Mr. Gerald Hane, trom Pacitic

Northwest Laboratory, for his invaluable help in securing data while on assignment in Japan and to Mr. Kenichi Matsui, Director of the Institute of Energy Economics, Tokyo, Japan, for providing much of that data. Mr. Joshua Miller, from Pacific Northwest Laboratory, helped to gather data for the U.S. and construct the database used in this analysis.

The author appreciates the guidance provided by Dr. James Edmonds in conducting this analysis and the comments on early drafts provided by Dr. Edmonds, Dr. W. Bradford Ashton, Dr. Joseph Roop, Dr. Michael Scott, and Mr. William Chandler, all from Pacific Northwest Laboratory. Thanks are also given to the peer reviewers: Dr. Joel Darmstadter, Resources for the Future; Ms. Mary Beth Zimmerman, Alliance to Save Energy; Dr. Joy Dunkerley, Office of Technology Assessment; Dr. Lee Schipper, Lawrence Berkeley Laboratory; and Dr. Kenji Yamaji, Central Research Institute of the Electric Power Industry, Japan. Any errors or omissions which remain are solely the responsibility of is author. 


\begin{abstract}
This report compares energy intensity in the U.S and Japan in 1985. Energy intensity is examined for each of the following end-use energy consuming sectors: residential and commercial, transportation, and industrial (manufacturing). In each sector, comparative measures of the relative energy intensity are developed.

The comparison indicates that when adjustments are made for certain differences between the two countries, cnergy intensity in the U.S. compares more favorably with Japan than when just the aggregate energy-to-gross-domestic-product ratio is used. For instance, climate and residential floor space explain a good portion of the difference between residential energy consumption in the U.S. and Japan. Likewise, although the U.S. requires about twice as much energy for passenger travel, it requires about half the energy for freight movement (when normalized for distance and vehicle capacity) compared with Japan. Finally, the U.S. manufacturing sector, as a whole, is about equal to Japan in terms of the amount of energy consumed in producing a dollar's worth of goods, in current dollars and using 1985 exchange rates.
\end{abstract}




\section{EXECUTTVE SUMMARY}

Pacific Northwest Laboratory ${ }^{(a)}$ conducted a comparative analysis of energy intensity in the U.S. and Japan in 1985. Energy intensity is the amount of energy required to produce a certain level of goods or services. According to aggregate International Energy Agency (IEA) data, the U.S. has one of the most energy-intensive economies, while Japan has one of the least. The purpose of this report is to construct and examine energy intensity measures that are more detailed than aggregate measures used by the IEA to see if they can better explain these differences.

The issue of energy intensity may become particularly critical if scientific findings on global climate change and greenhouse emissions lead to negotiations on restricting carbon emissions. The burning of fossil fuels is the most important anthropogenic source of carbon emissions. As this analysis shows, developing a consistent and fair set of goals for each country for carbon emissions, which are interlocked with energy intensity, may be a difficult task.

\section{S.1 ENERGY CONSUMPTION}

Before energy intensily is analyzed, energy consumption must be agreed upon for the two countries. Table S.1 shows both IEA data and Japanese and U.S. domestic data. Both sources seem to indicate that the greatest differences between the U.S. and Japan are for the residential and commercial, and the transportation sectors.

As Table S.1 shows, domestic energy consumption data cannot be totally reconciled with IEA published data. While good correspondence exists at the most aggregate level, that is, total primary energy requirements (TPER) and total final consumption (TFC), energy consumption differs widely in the end-use energy consuming sectors. 'This difference is particularly true for Japan's manufacturing energy consumption data (see footnotes to Table S.1).

Some attempt was made to resolve these differences when energy use was analyzed in each end-use sector, and at least part of the difference between IEA and Japanese domestic data for industry appears to be a result of the treatment of nonfuel use of energy. However, most of the discrepancy between IEA and domestic data reported by the Japanese Ministry of International Trade and Industry (MITI) needs to be resolved. This should be a goal for future studies.

\section{S.2 AGGREGATE ENERGY INTENSITY}

The IEA has calculated values for the energy-to-gross-domestic-product (E/GLP) ' tio, the most commonly used measure of energy intensity. The E/GDP ratio is the total amount of energy (E) consumed in a country divided by the value of goods and services produced (GDP). This ratio suggests that the U.S. is about twice as energy-intensive as Japan in $1985^{\text {(b) }}$

Table S.2 lists the E(TPER)/GDP ratio for the U.S. and Japan as well as some other aggregate energy intensity measures. If the value of goods produced by the manufacturing sector is used in the denominator instead of GDP, U.S. energy intensity rises to nearly three times that of Japan. This increase in intensity could be the result of a number of factors, including the relative share of the manufacturing sector to total GDP in the U.S. and Japan.

(a) Pacific Northwest Laboratory is operated for the U.S. Department of Energy by Battelle Memorial Institute.

(b) This ratio is calculated using 1980 exchange rates and prices. If 1985 exchange rates and prices were used, the U.S. would appear to be only about $60 \%$ more energy-intensive. 

Table s.1. Energy Consumption $(a, b)$
equivalent (MTOE)] [millions of tonnes of oil

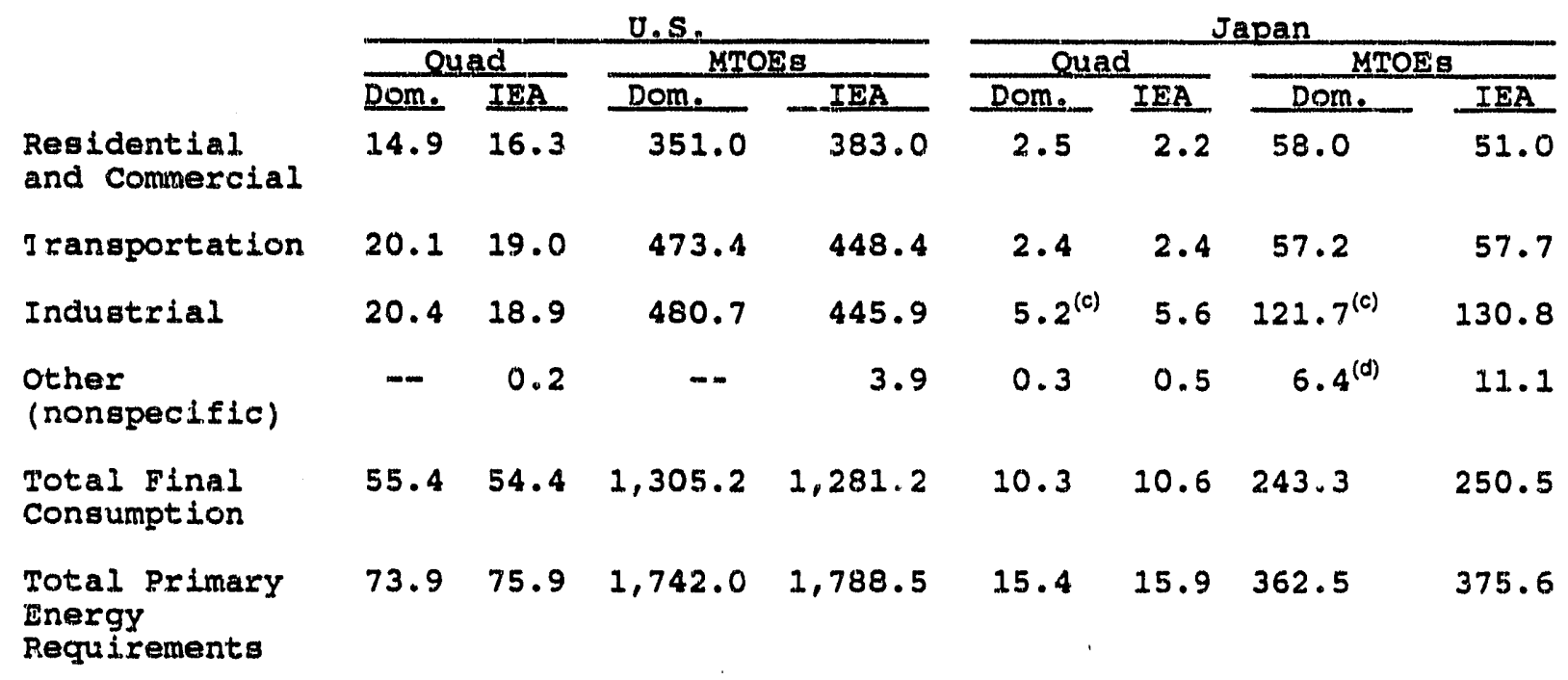

(a) Sources: Japan Institute of Energy Esonomics (JIEE) 1989; Organization for Economic Cooperation and Development (OECD)-IEA 1987a; U.S. Department of Energy-Energy Tnformation Administration (DOE-EIA) 1987a.

(b) Conversion Factor: 1 MTOE $=0.0424$ quad or 1 quad $=23.6$ MTOEs. Industrial includes agriculture; for the IFA, residential and commercial include public sexvice. All sectors include nonfuel uses of energy. Electricity is valued at heat value and does not include conversion losses. Totals may not sum because of independent rounding.

(c) A more detailed source for industrial energy consumption used in section 5 lists energy consumption as 200.3 MTOBs or 8.5 quad (MITI 1988).

(d) Iisted as "non-energy use other sectors" and "nonspecified other" in original data source (JIEE 1989). Not assignable to any particular end-use sector.

Table S.2. Aggregate Energy Intensi.ty Measures, 1985 (TOEs per 1980 $\$ 1,000$ U.S., unless otherwise noted) $(a, b)$

$\begin{array}{lllc} & \text { U.S. } & \text { Japan } & \text { U.S./Japan } \\ \text { E/GDP } & 0.58 & 0.31^{(\mathrm{c})} & 1.9 \\ \text { E/Man. Output } & 1.01 & 0.37 & 2.8 \\ \text { E/POp. (TOE/person) } & 7.47 & 3.11 & 2.4\end{array}$

(a) Sources: JIEE 1989; MITI 1988; OECD 1988a, 1988b; United Nations 1988; DOE-EIA 1987a; OECD-IBA 1987a; United Nations - Food and Agricultural Organization $1986 ;$ U.S. Department of Commerce (DOC) 1982.

(b) TPER is used for aggregate energy consumption.

(c) This number differs slightly from the IEA (0.29) because the

IEA uses 1980 exchange rates, while this study used 1985 rates. 
Table S.2 also shows energy consumption per parson in the two countries. This measure of energy intensity is not particularly good, as other studies have argued. For instance, the E/Pop. ratio shows that developing countries such as China appear less energy-intensive than either the U.S. or Japan. This is an artifact of China's huge population, however, and not its energy efficiency (Chandler 1988).

\section{S.3 RESIDENTIAL AND COMMERCIAL SECTOR}

Energy demand in the residential and commercial sector is a function of several variables including climate; living space; the thermal integrity of the building envelope; and the efficiency of the heating, ventilation, and air conditioning (HVAC) equipment. Adjustments were made for U.S. and Japanese differences in climate (outdoor temperature) for residential and commercial energy consumption and living space per person (residential energy consumption only).

Table S.3 shows residential energy intensity scaled by a number of factors. Both IEA and domestic data sources are used for the U.S. Among the intensity measures are energy consumption per household; population-weighted heating degree days (HDDs); square meter of living space per dwelling and per person; and living space per person, also adjusted for HDDs.

U.S. residential dwellings tend to be larger than Japanese dwellings. Also, Japan has more persons per household (larger families) and therefore less residential living space per person than the U.S. The climate for Japan also appears to be warmer. After adjusting for these factors, the seven-fold difference in residential energy consumption is reduced and the U.S. was found to be about twice as energy-intensive as Japan.

Table S.4 presents energy intensity data for the commercial sector in Mcal per square meter of building space. The data are for five building types: education, health care, lodging, retail/wholesale, and offices. The data for Japan are also adjusted for the difference in the number of HDDs in the U.S. and Japan (both upper and lower bound). However, lighting is probably the dominant use of energy in comaercial buildings in both the U.S. and Japan, and therefore commercial buildings are not as climate dependent.

When U.S. commercial building energy intensity is compared with unadjusted Japanese data, all U.S. building types except lodgings consume more energy per square meter than Japan. If the data are adjusted for HDDs, the U.S. compares more favorably with Japan. For instance, if the upper bound (cold winter in Japan) estimate is used for Japan, lodgings and health care facilities in the U.S. appear less energy-intensivs than their Japanese counterparts; if the lower bound (mild winter in Japan) is used, all U.S. commercial building types are less energy-intensive than Japan.

\section{S.4 TRANSPORTATION SECTOR}

Table S.5 presents energy consumption per passenger-kilometers (P-km), freight (tonne)-kilometers $(\mathrm{T}-\mathrm{km})$, and vehicle-kilometers (V-km) by mode (e.g., car) for the U.S. and Japan. One car P-km, for instance, is equivalent to one person traveling one kilometer by car. Two car P-km could either be two persons traveling one kilometer, or one person traveling two kilometers. Obviously, if more of the car P. $\mathrm{km}$ for a country are represented by persons traveling together, energy consumption per P-km traveled will tend to decrease.

Overall, the U.S. is about $75 \%$ more energy-intensive in passenger movement than Japan, apparently because of the overwhelming use of passenger cars in the U.S. versus mass transit in Japan. However, freight transport is only about one-half as energy-intensive in the U.S. as in Japan.

If an adjustment is made for mode choice for passenger and freight traffic, some interesting results are obtained. For instance, if Japanese travel habits were similar to those of the U.S. (i.e., relatively morf, car travel), Japanese passenger travel energy intensity would rise to $63.1 \times$ TOEs per $10^{6} \mathrm{P}-\mathrm{km}$, or slightly 


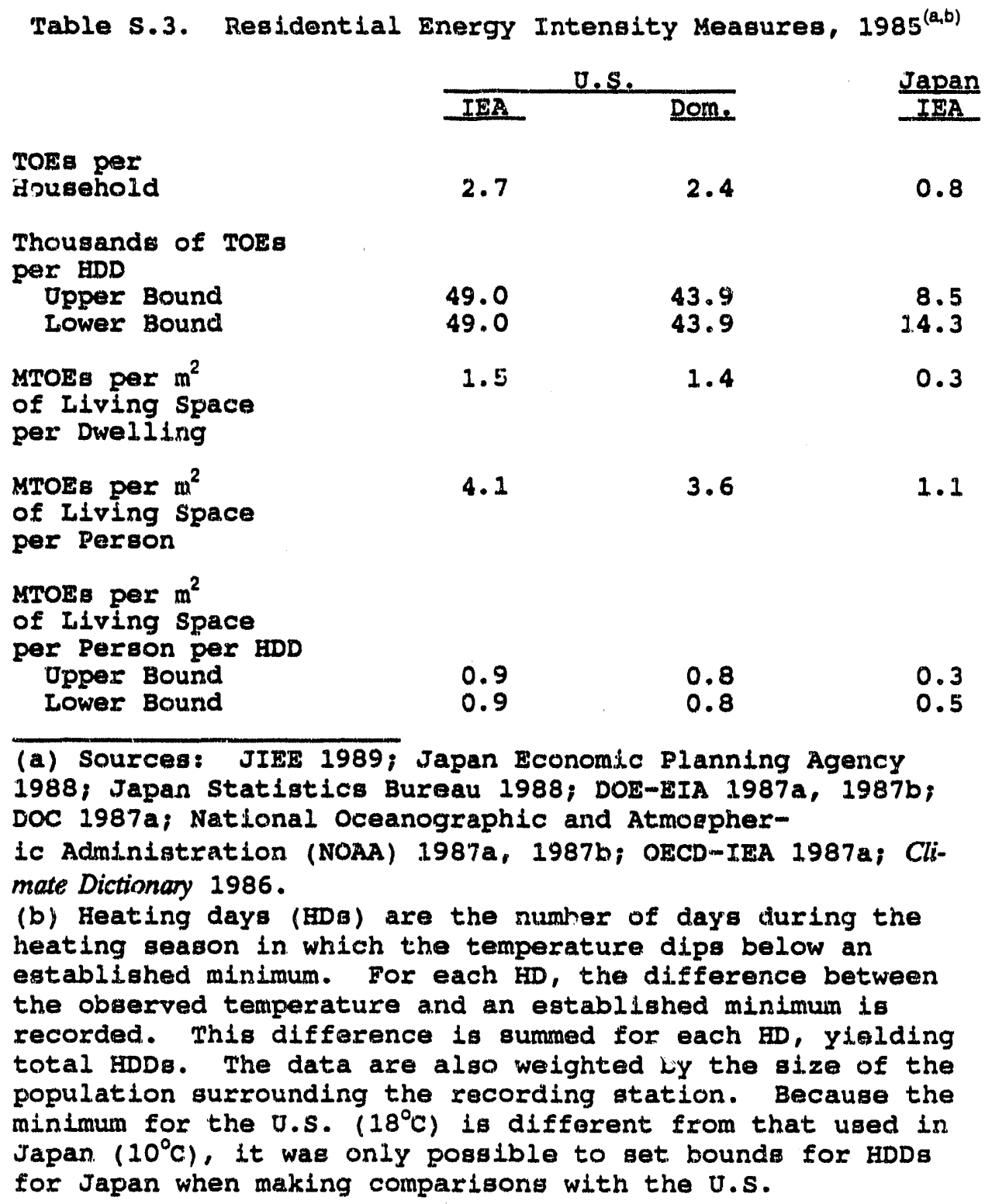

49.0

49.0

1.5

4.1

3.6

43.9

43.9

8.5

1.4

0.3

1.4 .3$$
3.6
$$

1.1

(a) Sources: JIEE 1989; Japan Economic Planning Agency 1988; Japan Statistics Bureau 1988; DOE-EIA 1987a, 1987b; DOC 1987a; National Oceanographic and Atmospheric Administration (NOAA) 1987a, 1987b; OECD-IEA 1987a; Climate Dictionary 1986.

(b) Heating days ( $\mathrm{HDB}$ ) are the number of days during the heating season in which the temperature dips below an established minimum. For each $\mathrm{HD}$, the difference between the observed temperature and an established minimum is recorded. This difference is summed for each $\mathrm{ED}$, Yielding total HDDs. The data are also weighted by the size of the population surrounding the recording atation. Because the minimum for the U.S. $\left(18^{\circ} \mathrm{C}\right)$ is different from that used in Japan $\left(10^{\circ} \mathrm{C}\right)$, it was only possible to set bounds for HDDs for Japan when making comparisong with the U.S.

greater than the U.S. Likewise, if the Japanese were to move freight more "like" the U.S. (e.g., more rail and less ship), Japan's freight energy intensity would decrease to $46.3 \times$ TOEs per $10^{6} \mathrm{~T}-\mathrm{km}$, which is still more energy-intensive than the U.S.

While U.S. cars and buses consume more energy for the same distance of travel than Japan, U.S. trains, planes, and trucks consume less energy. For planes and trains, the difference in energy consumed is probably a result of the long-haul, short-haul phenomena. Much more energy is required to set the train rolling or get the plane off the ground than to maintain cruising speed. In Japan, where the rail hauls and plane flights tend to be shorter than the U.S., it is not unexpected that energy consumption per $\mathrm{V}-\mathrm{km}$ for these modes of transport would be higher. For trucks, the greater amount of energy consumed (per kilometer) in Japan may reflect the amount of time spent in Japan's city driving as compared with U.S. interstate freight movement. 
Table S.4. Commercial Energy Intensity (Mcal per meter $\left.{ }^{2}\right)^{(a)}$

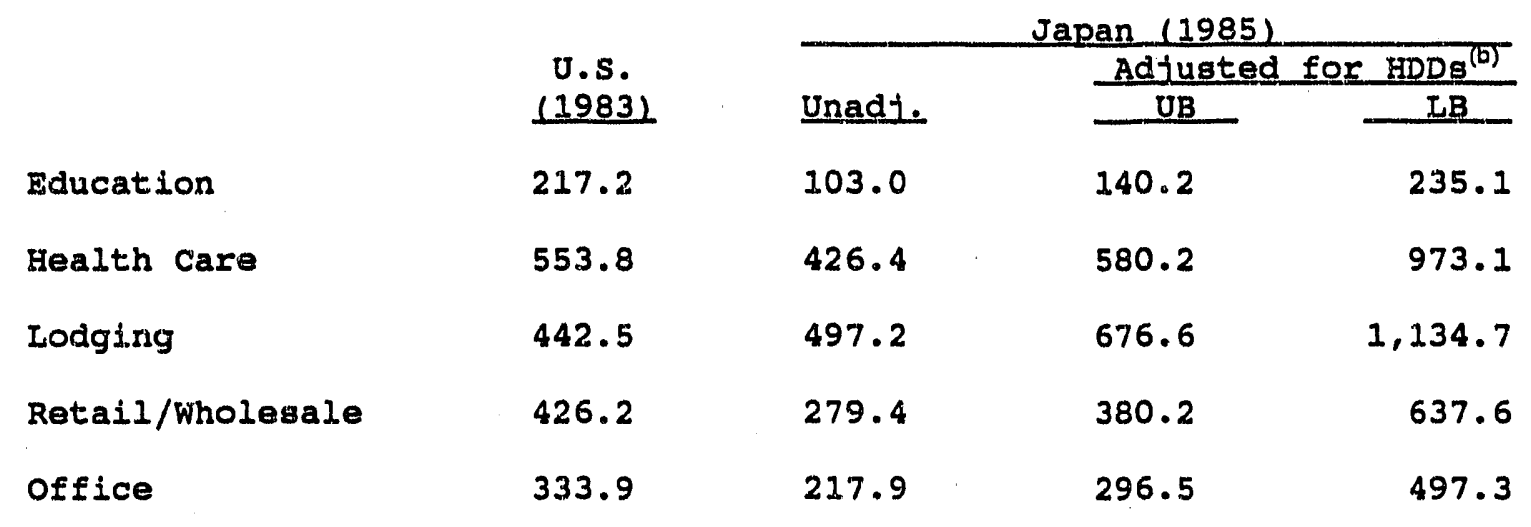

(a) Sources: Amols et al. 1988; JIEE 1987; DOE-EIA 1986.

(b) UB = upper bound; I,B = lower bound.

Table S.5. Transportation Energy Intensity by Mode, 1985 (TOE per $10^{6} \mathrm{P}-\mathrm{km}, \mathrm{T}-\mathrm{km}$, or $\left.\mathrm{V}-\mathrm{km}\right)^{(\mathrm{a}, b, c)}$

U.S.

\begin{tabular}{ccc} 
& U.S. & \\
\hline Pass. & Freight & Veh. \\
$(\mathrm{E} / \mathrm{P}-\mathrm{km})$ & $(\mathrm{E} / \mathrm{T}-\mathrm{km})$ & $(\mathrm{E} / \mathrm{V}-\mathrm{km})$
\end{tabular}

Mode

$\operatorname{Car}^{(d)}$

Bus $^{(\theta)}$

Truck

Rail.

Plane

Ship

All Trans. Mods 9

$\begin{array}{lcc}61.1 & -- & 105.3 \\ 25.4 & -- & 530.4 \\ -- & 90.9 & 100.7 \\ 44.3 & 7.7 & 290.4 \\ 78.2 & -- & 7.255 .4 \\ -- & 16.8 & -\end{array}$

61.5

36.5

117.3

\begin{tabular}{llc} 
& Japan \\
\hline Pass: & Freight & Veh. \\
$(\mathrm{E} / \mathrm{P}-\mathrm{km})$ & $(\mathrm{E} / \mathrm{T}-\mathrm{km})$ & $(\mathrm{E} / \mathrm{V}-\mathrm{km})$
\end{tabular}

65.0

14.0

$-$

4.9

62.5

2.9

35.2

$-$

104

90.7

104.2

232.0

146.4

$3,563.1$

$--$

22.8

$8,952.0$

61.6

121.6

(a) Sources: Japan Ministry of Transport 1988, 1987; DOC 1987a; JIEE 1987; U.S. Department of Transportation (DOT) 1987.

(b) Also, Davis, s. C., et al. 1988 (draft). 1988 Automated Transportation Energy Data Book. Oak Ridge National Laboxatory, Oak Ridge, Tennessee.

(c) Ship travel does not include pleasure boating. Pipeline data for the U.S., although very significant, are not included because similar data were not available for Japan.

(d) Does not include 2-wheel. vehicles (motorcycles). U.S. includes light trucks.

(e) U.S. includes school buses. 
The very large difference in rail energy use per V-km for the U.S. versus Japan may also be partly caused by the way in which train V-kms are counted. In the U.S., each rail car counts as a separate vehicle; in Japan, it may be that only the train engine is counted.

\section{S.5 MANUFACTURING SECTOR}

The manufacturing sector accounts for most of the energy consumed in the industrial sector for both the U.S. and Japan. As mentioned earlier, a large discrepancy exists between Japanese domestic and IEA sources of data for manufacturing energy consumption, partly because the IEA lists nonfuel uses of energy separately.

Comparable sources of data for manufacturing energy consumption were developed using the Manufacturing Eisergy Consumption Survey (DOE-EIA 1988) for the U.S. and MITI (1988) for Japan. Table S.6 shows manufacturing energy intensity for the U.S. and Japan using those sources. Both data sources include nonfuel uses of energy. While the IEA publishes energy consumption by industry for Japan, it does not provide such detail for the U.S.

In Table S.6, energy consumption is divided by the value of manufactured goods for each industry. The value of manufactured goods for Japan has been converted to 1985 U.S. dollars using the average exchange rate for 1985 .

As Table S.6 shows, overall energy intensity in the U.S. manufacturing sector is about equal to that of Japan in terms of the amount of energy consumed in producing a dollar's worth of goods. However, on an industry-by-industry basis, the U.S. is more energy-intensive than Japan in all but primary metals. The relative energy intensity of this industry, as is probably true of other industries, depends greatly on the "product mix" within these broader industry definitions. The primary metals industry consists of iron and steel, aluminum, copper, and other miscellaneous metals industries. The ratio of primary aluminum to

Table s.6. Manufacturing Energy Intensity, 1985 (10 $0^{3}$ TOEs per militons of 1985 U.S. dollaxs) ${ }^{(a)}$

\begin{tabular}{lrr} 
& U.S. & Japan \\
Food \& Tobacco & 71.1 & 35.6 \\
Textile and Leather & 57.5 & 46.9 \\
Wood and Wood Products & 102.7 & 11.0 \\
Paper, Pulp and Printing & 262.3 & 144.8 \\
Chemicals & 468.0 & 4.25 .5 \\
Non-Metallic Minerals & 382.5 & 313.7 \\
Primary Metals & 548.5 & 760.9 \\
Machinery & 31.8 & 16.2 \\
Transport Equipment & 25.2 & 21.0 \\
Other & 27.3 & 10.3 \\
Total Manufacturing & 180.6 & 174.3 \\
\hline (a) Sources: DOE-EIA 1988; MITI $1988 ;$ DOC 1987b. \\
1986; OECD-IEA 1987a.
\end{tabular}


raw steel production is higher in the U.S. than in Japan. Raw steel production is more energy-intensive than aluminum production, which may help to explain part of the higher energy intensity of the primary metals industry in Japan.

These results strongly depend on the exchange rate used and whether current or constant dollars (deflated to some base year) are used. If the data for the value of manufactured goods were to be deflated to 1980 U.S. dullars, U.S. manufacturing energy intensity would rise approximately $20 \%$ for each industry. This is equal to the relative difference in inflation rates for the two countries from 1980 to 1985. Furthermore, if a more recent exchange rate (e.g., 140\% to the dollar) is used to transform the value of output data, Japanese manufacturing energy intensity falls by about $65 \%$. These two effects combined would cause U.S. manufacturing energy intensity to be substantially greater than that of Japan.

\section{S.6 CONCLUSIONS AND RECOMMENDATIONS}

While the aggregate E/GDP ratio shows the U.S to be twice as energy-intensive as Japan, a closer examination of energy intensity yields some interesting results. The greatest percentage difference between U.S. and Japanese energy consumption is in the residential and commercial, and transportation sectors. The difference in industrial energy consumption in the U.S. versus Japan is roughly two to one, about the same as the ratio of G.DP when adjusted for exchange rates and inflation.

When adjustments are made for certain differences between the two countries, energy intensity in the U.S. compares more favorably with Japan. For example, although the U.S. requires about twice as much energy for passenger travel (to move one passager, one kilometer) it requires about half the energy for freight movement (when normalized for distance and vehicle capacity) compared with Japan. The U.S. manufacturing sector, as a whole, is about equal to Japan in terms of the amount of energy consumed in producing a dollar's worth of goods, although variations occur within individual industries. However, the U.S. consumes roughly twice the amount of energy in the residential sector per square meter, per person, after adjustments are made for climate. These measures highlight that differences in levels of energy cotsumption between the U.S. and Japan can be explained by factors other than energy efficiency. These factors can be thought of in terms of living standards and customs.

The discrepancy between IEA and domestic data sources needs to be resolved, primarily for Japanese manufacturing energy consumption. Also, a more comprehensive analysis of the residential and commercial sector is required, allowing for factors other than differences in floor space and climate (which relate primarily to space conditioning requirements).

A few subtle issues to be resolved in analyzing the transportation sector include school bus transport and incompatibility of data for train-kilometers. Finally, the measure developed for energy intensity in manufacturing is highly sensitive to factors such as exchange rates because financial measures instead of physical measures of output were used to scale energy consumption. However, exchange rates and other such transformations also affect the E/GDP ratio. Physical comparisons for manufacturing energy intensity, such as energy consumed per tonne of stone, clay, and/or glass, also are difficult to construct.

If future negotiations to reduce global carbon emissions are to include limits to individual countries, some adjustments must be made for important underlying differences among nations. The broad E/GDP measure of energy intensity masks these differences and may not paint a true picture of energy intensity. More disaggregate measures, such as energy consumed per passenger-kilometer ( $P-\mathrm{Km})$ travel, may be better measures and goals for reduced carbon emissions. 


\section{ACRONYMS AND ABBREVIATIONS}

\begin{tabular}{ll} 
I & Japanese Yen, the national currency of Japan \\
AER & Annual Energy Review \\
ASM & Annual Survey of Manufacturers \\
Btu & British thermal unit \\
CDs & cooling days \\
CDDs & cooling degree days \\
DOC & U.S. Department of Commerce \\
DOE & U.S. Department of Energy \\
dom. & domestic \\
E/GDP & energy-to-gross-domestic-product (ratio) \\
EIA & Energy Information Administration, U.S. Department of Energy \\
GDP & gross domestic product \\
GNP & grosi national product \\
HA & hectares \\
HDs & heating days \\
HDDs & heating degree days \\
HVAC & heating, ventilation, and air conditioning \\
IEA & International Energy Agency \\
IMF & International Monetary Fund \\
ISIC & international Standard Industrial Classification \\
JEE & Japan Institute of Energy Economics \\
JSIC & Iapanese Standard Industrial Classification \\
MECS & Manufacturing Energy Consumption Survey \\
MITI & Ministry of International Trade and Industry, Japan \\
MTOE & millions of tonne of oil equivalent \\
NOAA & National Oceanic and Atmospheric Administration \\
OECD & Organization for Economic Cooperation and Development \\
P-km & passenger-kilometer \\
PPP & purchasing power parities \\
quad & quadrillion Btu \\
SIC & Standard Industrial Classification \\
TFC & total final consumption \\
T-km & freight (tonne)-kilometer \\
TOE & tonne of oil equivalent \\
TPER & total primary energy requirements \\
UN & United Nations \\
V-km & vehicle-kilometer \\
& \\
\hline
\end{tabular}




\section{CONTENTS}

ACKNOWLEDGMENTS $\ldots \ldots \ldots \ldots \ldots \ldots \ldots \ldots \ldots \ldots \ldots \ldots \ldots \ldots \ldots \ldots \ldots \ldots \ldots$ iii

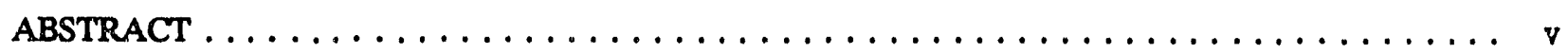

EXECUTTVE SUMMARY $\ldots \ldots \ldots \ldots \ldots \ldots \ldots \ldots \ldots \ldots \ldots \ldots$ vii

ACRONYMS AND ABBREVIATIONS $\ldots \ldots \ldots \ldots \ldots \ldots \ldots \ldots \ldots \ldots \ldots \ldots \ldots \ldots \ldots$

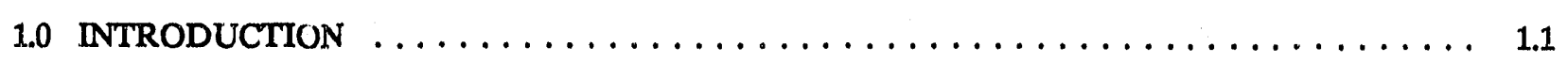

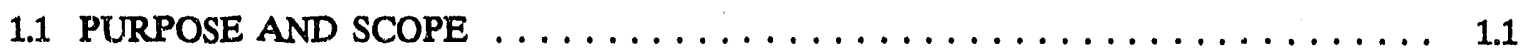

1.2 ORGANIZATION OF THIS REPORT $\ldots \ldots \ldots \ldots \ldots \ldots \ldots \ldots \ldots \ldots, 1.1$

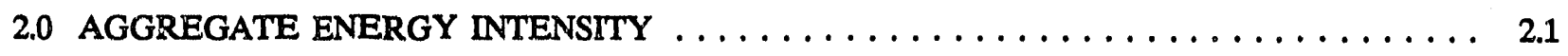

2.1 OVERVIEW OF THE E/GDP RATIO $\ldots \ldots \ldots \ldots \ldots \ldots \ldots \ldots \ldots \ldots, 2.1$

2.2 THE NUMERATOR, PRIMARY ENERGY CONSUMPTION $\ldots \ldots \ldots \ldots \ldots \ldots 2.1$

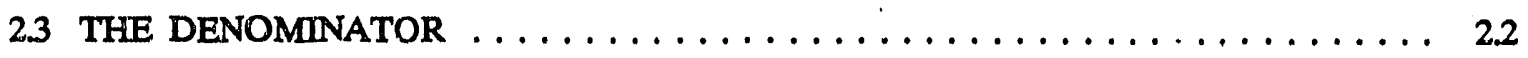

2.4 ALTERNATIVE AGGREGATE ENERGY INTENSITY MEASURES $\ldots \ldots \ldots, 2.2$

2.5 ENERGY INTENSITY CALCULATIONS FROM THE INTERNATIONAL

ENERGY AGENCY $\ldots \ldots \ldots \ldots \ldots \ldots \ldots \ldots \ldots \ldots \ldots \ldots, 2.3$

3.0 RESIDENTIAL AND COMMERCIAL SECTORS $\ldots \ldots \ldots \ldots \ldots \ldots \ldots \ldots \ldots . .1$

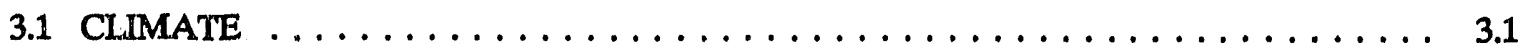

3.2 HOUSING CHARACTERISTICS $\ldots \ldots \ldots \ldots \ldots \ldots \ldots \ldots \ldots \ldots \ldots$

3.3 COMMERCIAL BUILDING CHARACTERISTICS $\ldots \ldots \ldots \ldots \ldots \ldots \ldots .3$

3.4 ENERGY CONSUMPTION IN THE RESIDENTIAL AND COMMERCIAL

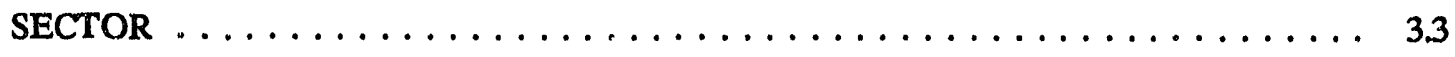

3.5 ENERGY INTENSITY IN THE RESIDENTIAL AND COMMERCIAL SECTOR $\ldots \ldots \ldots \ldots \ldots \ldots \ldots \ldots \ldots \ldots \ldots \ldots \ldots \ldots \ldots \ldots \ldots \ldots \ldots \ldots \ldots, \quad 3.5$

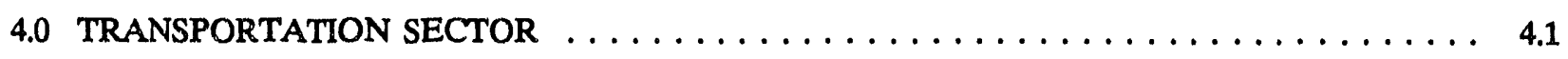

4.1 MODE OF TRAVEL $\ldots \ldots \ldots \ldots \ldots \ldots \ldots \ldots \ldots \ldots \ldots \ldots \ldots .1$

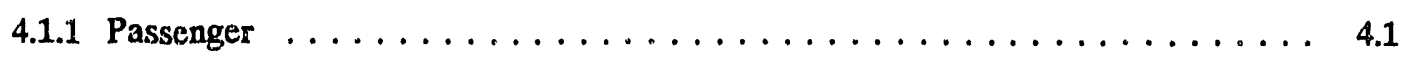

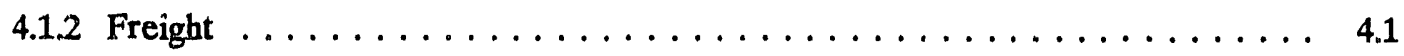


4.2 VEHICLE KLOMETERS TRAVELED $\ldots \ldots \ldots \ldots \ldots \ldots \ldots \ldots \ldots \ldots$

4.3 TRANSPORTATION ENERGY UISE $\ldots \ldots \ldots \ldots \ldots \ldots \ldots \ldots \ldots \ldots$

4.4 TRANSPORTATION ENERGY INTENSTTY $\ldots \ldots \ldots \ldots \ldots \ldots \ldots \ldots \ldots$

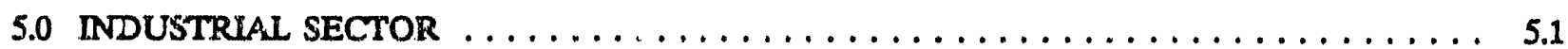

5.1 DEFINING THE INDUSTRIAL SECTOR $\ldots \ldots \ldots \ldots \ldots \ldots \ldots \ldots \ldots \ldots$

5.2 INDUSTRIAL ENERGY CONSIMPTION $\ldots \ldots \ldots \ldots \ldots \ldots \ldots \ldots \ldots \ldots$

5.2 .1 U.S. Manufacturing Energy Consumption $\ldots \ldots \ldots \ldots \ldots \ldots \ldots \ldots \ldots$

5.2 .2 Japrnese Manufacturing Energy Consuxption $\ldots \ldots \ldots \ldots \ldots \ldots$

52.3 Comparative Energy Consumption $\ldots \ldots \ldots \ldots \ldots \ldots \ldots \ldots$

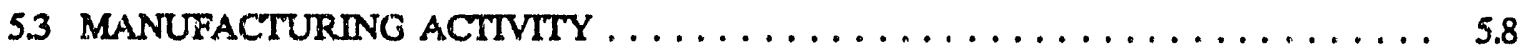

5.4 MANUFACTURING ENERGY INTENSTTY $\ldots \ldots \ldots \ldots \ldots \ldots \ldots \ldots$

6.0 CONCLUSIONS AND RECOMMENDATIONS $\ldots \ldots \ldots \ldots \ldots \ldots \ldots \ldots \ldots \ldots$

6.1 CONCLUSIONS $\ldots \ldots \ldots \ldots \ldots \ldots \ldots \ldots \ldots \ldots \ldots \ldots \ldots \ldots \ldots \ldots \ldots \ldots$

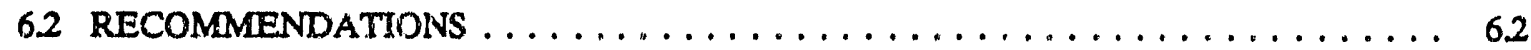

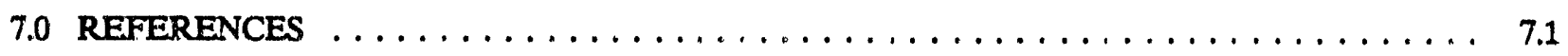




\section{TABLES}

S.1 Energy Consumption, $1985 \ldots \ldots \ldots \ldots \ldots \ldots \ldots \ldots \ldots \ldots \ldots \ldots \ldots \ldots \ldots$ viii

S.2 Aggregate Energy Intensity Measures, $1985 \ldots \ldots \ldots \ldots \ldots \ldots \ldots \ldots \ldots \ldots$. . . . . . . . . . . . .

S.3 Residential Energy Intensity Measures, $1985 \ldots \ldots \ldots \ldots \ldots \ldots \ldots \ldots \ldots \ldots \ldots$

S.4 Commercial Energy Intensity $\ldots \ldots \ldots \ldots \ldots \ldots \ldots \ldots \ldots \ldots \ldots \ldots \ldots \ldots \ldots \ldots$

S.5 Transportation Energy Intensity by Mode, $1985, \ldots \ldots \ldots \ldots \ldots \ldots \ldots \ldots \ldots$

S.6 Manufacturing En:rgy Intensity, $1985 \ldots \ldots \ldots \ldots \ldots \ldots \ldots \ldots \ldots \ldots \ldots \ldots$ xii

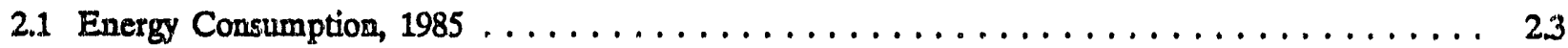

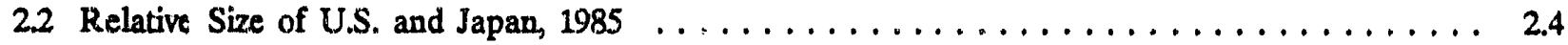

23 Aggregain Energy Intensity Measures, $1985 \ldots \ldots \ldots \ldots \ldots \ldots \ldots \ldots \ldots \ldots$

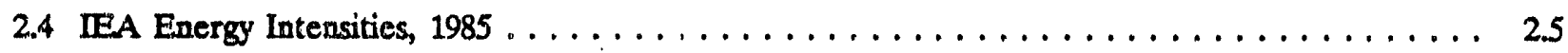

3.1 Japan's Annual Heating and Cooling Degree Days, $1985 \ldots \ldots \ldots \ldots \ldots \ldots \ldots . \ldots \ldots$

3.2 Housing Characteristics in the U.S. and Japan $\ldots \ldots \ldots \ldots \ldots \ldots \ldots \ldots \ldots \ldots$

3.3 Residential and Commercial Energy Use, $1985 \ldots \ldots \ldots \ldots \ldots \ldots \ldots \ldots \ldots \ldots \ldots$

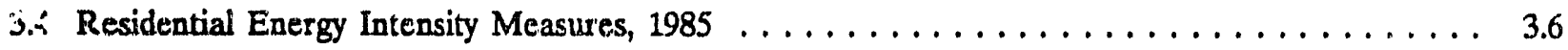

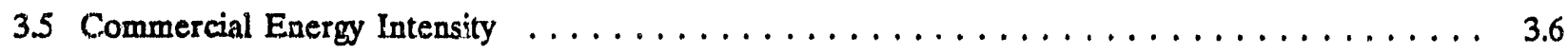

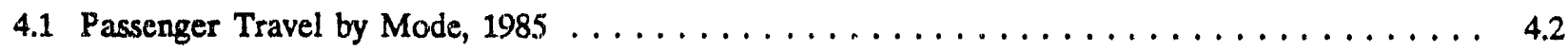

4.2 Freight Movement by Mode, $1985 \ldots \ldots \ldots \ldots \ldots \ldots \ldots \ldots \ldots \ldots \ldots \ldots \ldots \ldots$

4.3 Vehicle Kilometers Traveled, $1985 \ldots \ldots \ldots \ldots \ldots \ldots \ldots \ldots \ldots \ldots \ldots \ldots \ldots$

4.4 Capacity Factors per Vehicle, $1985 \ldots \ldots \ldots \ldots \ldots \ldots \ldots \ldots \ldots \ldots \ldots$

4.5 Total Transportation Energy Use, $1985 \ldots \ldots \ldots \ldots \ldots \ldots \ldots \ldots \ldots \ldots$

4.6 Transportation Energy Use by Mode, $1985 \ldots \ldots \ldots \ldots \ldots \ldots \ldots \ldots$

4.7 Transportation Energy Intensity by Mode, $1985 \ldots \ldots \ldots \ldots \ldots \ldots \ldots$

5.1 U.S. Industrial Classifications with Correspondence to Japanese
and International Classifications $\ldots \ldots \ldots \ldots \ldots \ldots \ldots \ldots \ldots \ldots \ldots \ldots \ldots \ldots \ldots \ldots \ldots$

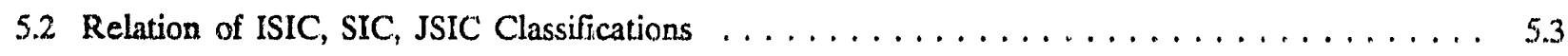


5.3 Industrial Energy Cousumption, $1985 \ldots \ldots \ldots \ldots \ldots \ldots \ldots \ldots \ldots \ldots \ldots$

5.4 U.S. Manufacturing Energy Consumption, $1985 \ldots \ldots \ldots \ldots \ldots \ldots \ldots \ldots \ldots \ldots$

5.5 Japanese Manufacturing Energy Consumption, $1985 \ldots \ldots \ldots \ldots \ldots \ldots \ldots \ldots$

5.6 Japanese Industrial Energy Consumption, $1985 \ldots \ldots \ldots \ldots \ldots \ldots \ldots \ldots$

5.7 Japanese Industrial Energy Consumption by Fuel, $1985 \ldots \ldots \ldots \ldots \ldots \ldots \ldots$

5.8 Manufacturing Energy Consumption in the U.S. and Japan, $1985 \ldots \ldots \ldots \ldots \ldots \ldots \ldots$

5.9 Value of Industrial Output, $1985 \ldots \ldots \ldots \ldots \ldots \ldots \ldots \ldots \ldots \ldots \ldots \ldots$

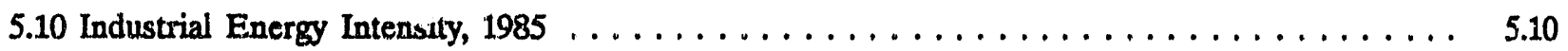

5.11 Industrial Energy Intensity Using All Data Sources, $1985 \ldots \ldots \ldots \ldots \ldots \ldots \ldots$ 


\subsection{INTRODUCTION}

Energy intensity in the U.S. versus other countries, particularly Japan, has been compared many times. The most commonly used measure for this comparison is the E/GDP ratio, the total amount of primary energy (E) consumed divided by the value of goods and services produced (GDP).

The International Energy Agency (IEA) publishes the most widely cited E/GDP series (OECD. IEA 1988). This ratio suggests that in 1985 the U.S. was twice as energy-intensive as Japan. Some analysts conclude, based on this ratio, that the U.S. is far less energy efficient than Japan and that more could be done to reduce U.S. energy intensity. Given recent trends in U.S. energy intensity and the burgeoning discussion of global climate change, the issue of energy intensity is likely to become still more important in the future (Geller 1989).

The E/GDP ratio, like GDP per capita, is a very aggregate measure. It is a bandy tool for quick comparisons but provides little insight into reasons for differences in this measure between two countries. More disaggregate measures are needed to help determine true differences in energy intensity and to help explain these differences (Podolak 1988). At least one person has made an attempt to disaggregate the E/GDP ratio, sharing out GDP and energy use along each of the end-use sectors (Ruggeri 1983); while others have attempted to analyze intensity by sector using overall GDP as a scaling factor (Darmstadter et al. 1977).

\subsection{PURPOSE AND SCOPE}

The purpose of this report is to provide a detailed comparison of energy intensity in the U.S. and Japan. This report investigates energy use and energy intensity in each of the end-use energy consuming sectors: the residential and commercial (buildings), transportation, and industrial sectors.

For each of the end-use sectors, measures of activity were developed, such as kilometers traveled by mode of transport, the value of industrial production by industry, and the size of homes and dwelling space per person. These activities have a bearing on energy consumption. Examining the amount of energy consumed to carry out these activities (e.g., energy consumption per kilometer of travel) indicates the degree to which differences in energy intensity are attributable to "true" energy efficiency' as opposed to, for example, living standards (average residential living space per person). Other parameters that may affect energy intensity but are not necessarily synonymous with energy efficiency are geography, culture, resource endowment, government policies, and population density.

The year used for this analysis is 1985 , chosen primarily because it is the most recent year for which detailed industrial (manufacturing) energy consumption data are available for the U.S. [U.S. Department of Energy - Energy Information Administration (DOE-EIA 1988)]. This repor' does not analyze the electrical transformation (utility) sector, nor does it provide a full decomposition of the factors that determine aggregate energy consumption (for example, Boyd et al. 1987).

Comparisons have been made of the link between time series data for energy consumption and GNP growth (Kraft and Kraft 1978), including intercountry comparisons (Yu and Jai-Young 1985). However, this study encompasses just a single year, 1985. Furthermore, this study does not attempt to establish a causal link between energy consumption and GNP but rather compares the relative energy intensities of the U.S. and Japan.

\section{ORGANIZATION OF THIS REPORT}

This report is divided into seven sections. Section 2.0 examines overall energy intensity and various measures of this aggregate. Sections 3.0 through 5.0 investigate energy intensity in the residential and commercial, transportation, and industrial sectors, respectively. Section 6.0 contains conclusions and recommendations from this analysis, and Section 7.0 contains the references. 


\subsection{AGGREGATE ENERGY INTENSITY}

This section provides an analysis of overall aggregate energy intensity in the U.S. and Japan. Section 2.1 provides an overview of the E/GDP ratio and describes some of the issues surrounding the use of this measure. In Section 2.2 the numerator (E) of the E/GDP ratio is discussed. Various sources of data are compared in order to attempt to arrive at total energy consumption. Section $\mathbf{2 . 3}$ briefly describes the denominator (GDP). Section 2.4 presents alternative aggregate energy intensity measures, while Sectinn 2.5 attempts to recreate the E/GDP series produced by the IEA (OECDIEA 1988).

\subsection{OVERVIEW OF THE E/GDP RATIO}

Energy intensity can be described as the average amount of energy used to perform a certain activity. One aggregate measure of energy intensity is the total amourt of energy consumed by a country to produce a slate of goods and services. The most popular measure is the ratio of the quantity of primary energy $(E)$ consumed divided by the value of goods and services produced (GDP). ${ }^{\left({ }^{()}\right)}$The shorthand notation is simply the E to GDP ratio (E/GDP).

The E/GDP ratio, like GDP per capita, is so aggregate as to gloss over a number of important issues. For instance primary energy consumption (E) is composed of several different energy forms (e.g., oil, natural gas, and hydroelectric), each of which must be converted to common units before they can be summed to total consumption. This conversion requires assumptions of the relative heat value (Btu content) of the fuels.

Likewise, GDP measures the (dollar) value of output, as opposed to the quantity of a product (e.g., tons of steel). Given perfect markets, summing the value of products might be an acceptable method of

(a) Gross domestic product (GDP), which connts only domestically produced goods and services, is more commonly used for this purpose than gross national product (GNP), which also includes production of foreign subsidiaries. comparing the relative quantity of energy required to produce the value of those products. However, before making comparisons between countries, the currency of one country must be converted to the other. This conversion introduces problems of exchange rates and comparable worth of goods between two countries.

Alternative measures might use the value of total energy consumed or perhaps the quantity of goods and services produced. Both of these measures have problems. For instance, energy prices are distorted by differing tax and regulatory policies. Also, when the level of aggregation is high, it becomes nearly meaningless to sum tons of iron and steel with tons of stone, clay, and glass (to say nothing of services) in order to compare energy intensity.

Beyond the difficulties in determining a suitable aggregate measure of energy intensity is the question of the appropriateness of such a broad measure. The value of this measure is in its simplicity and therefore relative ease of comparison among countries. However, its simple construct also presents a danger for indiscriminate usage because it does not consider a host of determinants for energy consumption that may vary markedly between two countries. These determinants might be energy prices, life styles, and customs, in addition to the relative efficiency with which energy is used to produce value such as a tonne of steel or travel in an automobile.

\subsection{THE NUMERATOR, PRIMARY ENERGY CONSUMPTION}

The numerator of the E/GDP ratio is total energy consumption. This could be either total "primary" energy requirements (TPER) or total "final" consumption (TFC), but TPER is most frequently used. Primary energy includes energy consumed directly, as well as the energy required to change energy from one form to another (most notably electrical transformation). In the case of hydro and nuclear electricity generation, an assumed heat equivalent of coal or oil and an assumed efficiency of conversion are used to derive energy consumption for these transformations. 
Final energy consumption, on the other hand, is just the amount of energy that is consumed by the end-user. In this case, the end-user would be the residential and commercial, transportation, and industrial sectors. The major difference between "primary" energy consumption and "final" energy consumption is the conversion process to produce electricity. TPER and TFC can also include "nonfuel" uses of energy, such as methane used as a petrochemical feedstock.

Before energy consumption can be aggregated to a total, such diverse measures as barrels of oil or cubic feet of natural gas must be converted to common units. In the U.S., the common unit of expression is quadrillion $\left(10^{15}\right)$ Btu or simply quads of energy. The IEA, on the other hand, uses millions of tonnes of oil equivalent (MTOEs). ${ }^{(4)}$

Tahle 2.1 contains data for both primary and final energy consumption for the U.S. and Japan in 1985. The data are provided in both quads and MTOEs. Final energy consumption is further divided into the residential and commercial, transportation, and industrial sectors. Both domestic (dom.) and IEA data sources have been used to construct this table [Japan Institute of Energy Economics (JIEE) 1989; OECD-IEA 1987a; and DOE-ELA 1987a].

As Table 2.1 shows, figures for TFC and TPER are reasonably close for the domestic and IEA data sources. However, the totals for each of the end-use consuming sectors vary significantly between the two data sources. This difference exists for most U.S. and Japanese sectors (see footnotes in Table 2.1 for Japanese industrial sector). Some attempt will be made in later sections to reconcile these differences.

\subsection{THE DENOMINATOR.}

So far, the discussion of energy intensity has referred to the amount of energy consumed per value of output produced (E/GDP). The denominator of this ratio lends scale to the quantity of energy

(a) One MTOE is equivalent to approximately 0.0424 quad of energy. Alternatively, 1 quad equals about 23.6 MTOEs. consumed, given the two countries' differences in size. Other measures could be used to scale energy consumption.

Table 2.2 shows several measures of the relative size of the U.S. and Japan. Along with GNP or GDP, already discussed, are the value of output of the manufacturing sector, land area, and population. All the data are for 1985 .

Column 3 in Table 2.2 shows that overall, the U.S. economy is roughly three times the size of Japan. Both the value of manufactured output and the population of the U.S. are about twice that of Japan. The most profound difference in this table is land area.

\subsection{ALTERNATIVE AGGREGATE ENERGY INTENSITY MEASURES}

Table 2.3 shows several different energy intensity measures. The data are derived using TPER from Table 2.1 and data from Table 2.2. For ease of comparison with IEA data, the financial data have been converted to constant 1980 currencies using the relative deflator for each country. The data then were converted to U.S. dollars using the average $1985 \mathrm{ex}$ change rate. ${ }^{(b)}$

As Table 2.3 shows, the relative difference in energy intensity between the U.S. and Japan does not vary much using either GDP or GNP. The gap widens somewhat when looking at TPER as a portion of the value of manufactured output. Several factors could explain this gap, inciuding the relative share of GNP produced by the manufacturing sector. The more explicit analysis of manufacturing energy intensity is treated in a later section.

Per-capita, the U.S. consumes about 2.5 times as much energy as Japan. One could argue that this would be a fair basis for comparison given that people are the eventual consumers of energy (or energy embodied in products). Other studies have used this measure to show that developing countries, with high populatious and low stages of

(b) The 1985 exchange rate was 238.5 per U.S dollar. The 1980 exchange rate was 226.7 per U.S dollar. 
Table.2.1. Energy Consumption, 1985 (millions of tonnes of oil equivalent (MTOE) $]^{(a, b)}$

\begin{tabular}{|c|c|c|c|c|c|c|c|c|}
\hline & \multicolumn{4}{|c|}{ U.S. } & \multicolumn{4}{|c|}{ Japan } \\
\hline & \multicolumn{2}{|c|}{ ouad } & \multicolumn{2}{|c|}{ MTOEg } & \multicolumn{2}{|c|}{ ouad } & \multicolumn{2}{|c|}{ MTOES } \\
\hline & Dom. & IEA & Dom. & IEA & Dom. & IEA & Dom. & IEA \\
\hline $\begin{array}{l}\text { Regidential } \\
\text { and Commercial }\end{array}$ & 14.9 & 16.3 & 351.0 & 383.0 & 2.5 & 2.2 & 58.0 & 51.0 \\
\hline Transportation & 20.1 & 19.0 & 473.4 & 448.4 & 2.4 & 2.4 & 57.2 & 57.7 \\
\hline Industrial & 20.4 & 18.9 & 480.7 & 445.9 & $5.2^{(0)}$ & 5.6 & $121.7^{(c)}$ & 130.8 \\
\hline $\begin{array}{l}\text { Other } \\
\text { (nonspecific) }\end{array}$ & -- & 0.2 & - & 3.9 & 0.3 & 0.5 & $6.4^{(d)}$ & 11.1 \\
\hline $\begin{array}{l}\text { Total Final } \\
\text { Consumption }\end{array}$ & 55.4 & 54.4 & $1,305.2$ & $1,281.2$ & 10.3 & 10.6 & 243.3 & 250.5 \\
\hline $\begin{array}{l}\text { Total Primary } \\
\text { Energy } \\
\text { Requirements }\end{array}$ & 73.9 & 75.9 & $1,742.0$ & $1,788.5$ & 15.4 & 15.9 & 362.5 & 375.6 \\
\hline
\end{tabular}

(a) SOU.Ces: TIEE 1989; DOE-EIA 1987a; OECD-IEA 1987a.

(b) Conversion Factor: $1 \mathrm{MTOE}=0.0424$ quad or 1 quad $=23.6 \mathrm{MTOEs}$. Industrial includes agriculture; for the IEA, residential and commercial include public service. All sectors include nonfuel useg of energy. Electricity valued at heat value and does not include conversion losses. Totals may not sum becaure of independent rounding.

(c) A more detailed source for industrial energy consumption used in section 5 lists energy consumption as 200.3 MTOEs or 8.5 quad (MITI 1988).

(d) Listed as "non-energy use other sectors" and "nonspecified other" in original data source (JIEE 1989). Not assignable to any particular end-use sector.

development, are less energy-intensive than developed countries such as the U.S. or Japan (Kellogg and Schware 1981). However, an effective argument has been raised against such a comparison, showing that a country can have a relatively low $\mathrm{E} /$ pop rate yet still be quite energyintensive (Chandler 1988).

Finally, just for comparison purposes, energy consumption per hectare (HA) is presented. This rather crude measure shows that the U.S. consumes about one-fifth the energy per hectare as Japan. Land size is not as good a determinant in explaining energy use as might be other geographically related data such as urban density (for travel) and temperature (for space heating and cooling demand).

\subsection{ENERGY INTENSITY CALCULATIONS FROM THE INTERNATIONAL ENERGY AGENCY}

The IEA publishes an annual series on energy intensity in IEA countries (OECD-IEA 1987a). The series uses TPER or TFC data from Energy Balances. The data source for GDP is cited as the OECD publication Main Economic Indicators (1988a). However, Main Economic Indicators does not have GDP data for the U.S. and Japan, but instead lists the GNP of these countries. However, GDP data can be found in the OECD National ACcounts (1988b), as can relative exchange rates (see Table 2.4). 
Table 2.2. Relative Size of U.S and Japan, 1985 (bilitons

of dollars unless otherwise noted)

\begin{tabular}{|c|c|c|c|}
\hline & U.S. & Japan & U.S./Japan \\
\hline $\operatorname{GNP}^{(\otimes)}$ & $4,015.0$ & $1,330.8$ & 3.0 \\
\hline GDP $P^{(P)}$ & $3,960.0$ & $1,325.2$ & 3.0 \\
\hline $\begin{array}{l}\text { Manufacturing } \\
\text { Value of output }\end{array}$ & $2,286.5$ & $1,114.8$ & 2.1 \\
\hline $\begin{array}{l}\text { Population } \\
\text { (millions) }^{(\phi)}\end{array}$ & 239.3 & 120.8 & 2.0 \\
\hline $\begin{array}{l}\text { Land Area } \\
(1,000 \text { hectare })\end{array}$ & 916,660 & 37,643 & 24.4 \\
\hline
\end{tabular}

(a) Source: OECD 1988a. The GNP value differs between OECD $1988 \mathrm{a}$ and OECD $1988 \mathrm{~b}$ data sources. Japanese are converted to U.S. dollarg using $238.54 \mathrm{Y}$ to $\$ 1$ U.S., the average exchange rate for 1985.

(b) Source: ORCD 1988b.

(c) Sources: J.S. value of output - U.S. Department of Commerce (DOC) 1982; Japan value of output - MITI 1988. Manufacturing Value of output is the dollar value of products produced by manufacturing industries, which consists of sales adjusted for inventory changes. These numbers are larger than manufactures' contribution to GNP by the value of purchased materials.

(d) Source: United Nations (UN) 1988.

(e) Source: UN - Food and Agrlcultural Oxganization (FAO) 1986.

Table 2.3. Aggregate Energy Intensity Measures, 1985 (TOEs per $1980 \$ 1,000$ U.S., unless otherwise noted) (a.

U.S. Japan U.S./Japan

$\begin{array}{llll}\text { E/GNP } & 0.58 & 0.31^{(\text {) }} & 1.9 \\ \text { E/GDP } & 0.58 & 0.31 & 1.9 \\ \text { E/Man. Output } & 1.01 & 0.37 & 2.8 \\ \text { E/Pop (TOE/person) } & 7.47 & 3.11 & 2.4 \\ \text { E/Area (TOE/hectare) } & 1.95 & 9.98 & 0.2\end{array}$

(a) Eriergy consumption (E) is TPER from IEA.

(b) Sources: JIEE 1989; MITI 1988; OECD 1988a, 1988b;

UN 1988; DOE-EIA 1987a; OECD-IEA 1987a; UN-FAO 1986; DOC 1982.

(c) This number differs slightly from the IEA (0.29)

because the IEA uses 1980 exchange rates, while this study used 1985 rates. 
Table 2.4. IEA Energy Intengities, $1985^{\text {(a) }}$

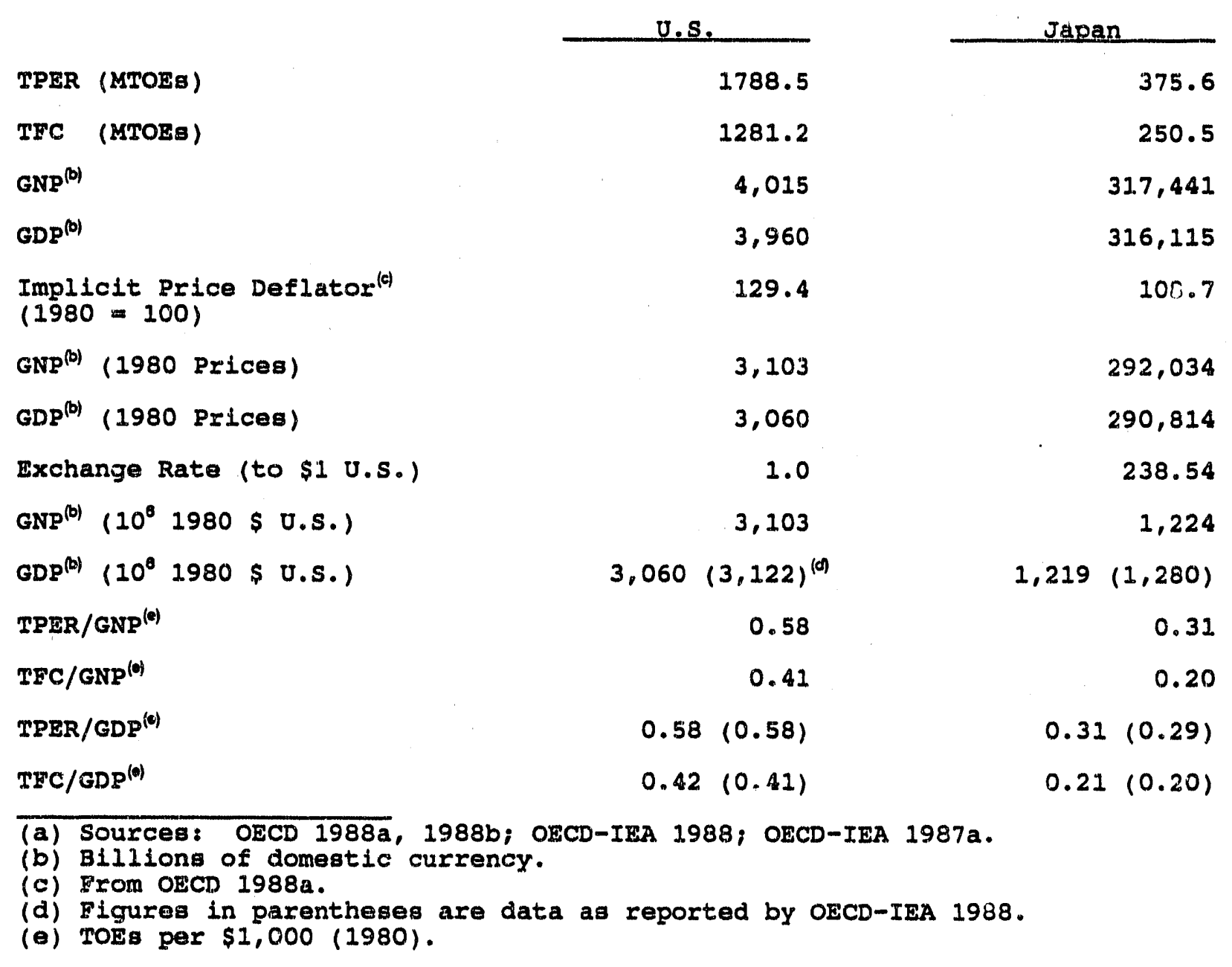

As Table 2.4 shows, the energy intensity ratio is the same using either GNP or GDP for the U.S. or Japan. Likewise, the U.S. energy intensity ratio is about twice that of Japan using either TPER or TFC. Sorne difficulty occurred in exactly reproducing the energy intensity ratios as reported by the IEA (OECD-IEA 1988). The problem appears to be in the exchange rate used.

The IEA deflates the GDP series to 1980 prices and then uses 1980 exchange rates to convert the data to commou currencies (OECD-IEA 1988). The exchange rate in 1980 was 226.7 per U.S. dollar (OECD 1988b). This study uses the 1985 exchange rate of 238.5 per U.S. dollar. For comparison, the purchasing power parity (PPP) between the U.S. and Japan was 259 per U.S. dollar in 1980 and 222 per U.S. dollar in 1985 (OECD 1988b). PPPs allow financial data from different countries to be expressed in a common currency. This is accomplished by evaluating the worth of a common "basket of goods" between countries. The relative change in value of this basket of goods hetween countries, over time, should capture differences in inflation rates and not speculative changes in exchange rates. 


\subsection{RESIDENTIAL AND COMMERCIAL SECTORS}

In this section, energy intensity in the residential and commercial sectors is analyzed. In Section 3.1, the effect of Japanese and U.S. climate on energy consumption is discussed. In Sections 3.2 and 3.3 housing and commercial building characteristics, which are important to energy consumption in the residential and the commercial sectors, are examined. Section 3.4 presents data on energy consumption, while Section 3.5 analyzes energy intensity in the residential and commercial sectors.

\subsection{CLIMATE}

Climate affects residential and commercial energy corsumption in that energy is required to condition living and office space to acceptable temperatures. The amount of energy required for that conditioning depends on the outdoor temperature, the integrity of the building envelope, the efficiency of the space-conditioning equipment (e.g., heat pump, air conditioner, chillers), as well as accepted norms for comfort in the country or region being studied. Energy is also required to operate nonspaceconditioning equipment (e.g., water heaters, lights, and refrigerators). Energy consumption for these uses is also partly driven by climate.(2)

Japan, like the U.S., has extreme climates within its territory. These climates range from frigid winter temperatures on central Hokkaido Island to tropical conditions on Okinawa. However, the important determinant of climate-related energy use is not the amount of territory that falls under one climate regime or the other, but the climate experienced by the populace either in their homes of offices.

The established methodology for determining the average temperature experience is to break the year into winter (heating) and summer (cooling) seasons. If annual temperatures were averaged without such a division, temperature extremes would tend to

(a) For example, the dcmand for artificial lighting is a function of latitude because latitude will determine the average amount of daylight per year. Outdoor temperature will also affect inlet water temperatures, which will impact water heating requirements. Even refrigerators may experience greater energy demands if inside temperatures fluctuate with outdoor temperatures. cancel and therefore less accurately depict energy demand required for space conditioning.

Mean daily temperature readings during the heating and cooling seasons are subtracted from a benchmark temperature (for instance, number of degrees below $60^{\circ} \mathrm{F}$ during the heating season). Each day below (heating) or above (cooling) the benchmark temperature for that season is designated as a heating or cooling day. The difference between the mean temperature reading and the benchmark temperature is summed for each heating or cooling day to yield annual data for heating degree days (HDDs) or cooling degree days (CDDs). The data are population-weighted to simulate the population's climate experience.

Table 3.1 contains data on heating and cooling degree days for Japan's five largest cities. As the table shows, the benchmark temperature for HDDs is $10^{\circ} \mathrm{C}\left(50^{\circ} \mathrm{F}\right)$ and $\mathrm{CDDs}$ is $24^{\circ} \mathrm{C}\left(75^{\circ} \mathrm{F}\right)$. Also included is the actual number of days in which the temperature fell below $10^{\circ} \mathrm{C}$ [heating day (HD)] or rose above $24^{\circ} \mathrm{C}$ [cooling day $(C D)$ ].

The data for Japan were not weighted for population in the original data source. An attempt has been made to derive total average HDDs and CDDs using population and degree day data for these cities. Since the Greater Tokyo metropolitan area is home to approximately $25 \%$ of the population of Japan, thi $i$ is probably a reasonable estimate (Japan Economic Planning Agency 1988).

The HDDs and CDDs for the U.S are 4,772 and 1,154, respectively [National Oceanic and Atmospheric Administration (NOAA) 1987a, 1987b] ${ }^{(b)}$ The calculation methodology for those data differs from that in I able 3.1 in that the benchmark temperature for the U.S. is $18^{\circ} \mathrm{C}\left(65^{\circ} \mathrm{F}\right)$ for both HDDs and CDDs. Because heating or cooling degrees are measured as the difference between the benchmark and the mean temperature reading, U.S. and Japanese data are not readily comparable.

(b) HDDs for the U.S. are normally calculated using a heating season that runs from July of one year through June of the fol-lor ing year. The data cited here are for January through December 1985, weighted by 1980 population. 
Table 3.1. Japan's Annual Heating and Cooling Degree Days, 1985 ${ }^{(a)}$

\begin{tabular}{|c|c|c|c|c|c|}
\hline city & $\begin{array}{l}\text { Population } \\
\quad\left(10^{3}\right) \\
\end{array}$ & $\begin{array}{r}H D D s \\
\left(10^{\circ} \mathrm{C}\right) \\
\end{array}$ & HDs & $\begin{array}{c}C D D_{s} \\
\left(24^{\circ} \mathrm{C}\right) \\
\end{array}$ & $\mathrm{CDg}$ \\
\hline Tokyo & 8,355 & 900 & 119 & 130 & 65 \\
\hline Yokohama & 2,993 & 912 & 122 & 96 & 58 \\
\hline Osaka & 2,636 & 850 & 118 & 237 & 83 \\
\hline Nagoya & 2,116 & 1,069 & 128 & 142 & 69 \\
\hline Sapporo & 1,543 & 2,638 & 197 & -- & 0 \\
\hline Average (population weighted) & 17,643 & 1,067 & 127 & 143 & 61 \\
\hline
\end{tabular}

(a) Sources: Japan Statistics Bureau 1988; Climate Dictionary 1986.

As the data in Table 3.1 show, in absolute terms the total number of HDDs are greater than CDDs in both the U.S. and Japan, even after allowing for the different base temperatures for HDDs and CDDs in the Japanese data. From a national perspective, therefore, space heating requirements seem to be more crucial than space cooling for both the U.S. and Japan.

At least one source uses a consistent methodology for calculating HDDs for the U.S. and Japan (Ketoff et al. 1987). However, those data do not appear to be populacion weighted and therefore are not as useful in analyzing energy use for space heating. A direct comparison of population-weighted HDDs for the U.S. and Japan is ideal but difficult to derive given the differing benchmark temperatures and the calculation methodology for HDDs.

The Japanese HDDs can be adjusted to provide comparisons with the U.S., but this poses two problems. First, an $8^{\circ} \mathrm{C}$ temperature differential exists between the U.S. $\left(18^{\circ} \mathrm{C}\right)$ and Japanese $\left(10^{\circ} \mathrm{C}\right)$ benchmark temperatures. Second is the need to know the number of additional heating days that would have been recorded in Japan if the U.S. benchmark had been used instead of the Japanese benchmark. The methodology used here is to develop upper (cold winter in Japan) and lower (mild winter in Japan) bounds for the total numbers of HDDs in Japan.

To develop an upper bound, all days in the year that were not cooling days (61) in Japan were assumed to be heating days $(365-61=304)$. Next, the mean temperature for each of these days was assumed to be just $10^{\circ} \mathrm{C}$ (the coldest temperature possible without being recorded as an HDD under the Japanese system). Each of these 304 days is multiplied by the full difference in benchmark temperatures $\left(8^{\circ} \mathrm{C}\right)$ to calculate an upper bound on the additional number of HDDs which would have occurred if the Japanese used the U.S. benchmark temperature. Adding these additional HDDs to the original heating degree days, the full upper bound would then be as follows:

$$
\begin{gathered}
\text { Upper Bound }=\text { Original HDDs }+ \\
(365 \cdot \text { Cooling Days }) * 8
\end{gathered}
$$

Given the original HDD value for Japan of 1,067 (@ $10^{\circ} \mathrm{C}$ ) and a population-weighted average of 61 cooling days, the upper bound would be 3,497 HDDs for Japan in 1985.

The lower bound assumes that only the heating days originally recorded in Japan (127) were cold enough to qualify as heating days using either benchmark temperature. All other days during the year were assumed to be warmer than $18^{\circ} \mathrm{C}$ (and therefore also warmer than $10^{\circ} \mathrm{C}$ ). The lower bound would simply be as follows:

Lower Bound $=$ Original HDD $+($ Heating Days $) * 8$ 
or a total of $2,085 \mathrm{HDDs}$ in 1985 . Both the lower and upper bounds for Japan are less than the population-weighted HDDs for the U.S., which means that, overall, Japanese citizens experience a milder winter than U.S. citizens. This HDD data will be used, a'ong with information presented in the following two sections, to examine energy intensity in the residential and commercial sectors in Section 3.5.

\subsection{HOUSING CHARACTERISTICS}

While Japanese per-capita income may be approaching or even exceeding that in the U.S., Japanese housing, at least as far as size is concerned, lags behind the U.S. and most western countries. Much of the Japanese population is concentrated in the Tokyo metropolitan area. Homes tend to be smallest in this area, with an average floor space per owner-occupied home of around $90 \mathrm{~m}^{2}\left(968 \mathrm{ft}^{2}\right)$. The average size of rented housing is significantly smaller; only $35 \mathrm{~m}^{2}\left(377 \mathrm{ft}^{2}\right)$ per dwelling (Japan Economic Planning Agency 1989).

Table 3.2 presents data for the U.S. and Japanese residential sector. As the table shows, the number of U.S. households is nearly 2.5 times that of Japan. The U.S. population is only twice that of Japan, so the number of persons per household in Japan tends to be larger than in the U.S. Home ownership raies and numbir of rooms per home are roushly equivalent between tiie "J.S. and Japan, while new U.S. homes tend to be larger than their Japanese counterparts.

The major differences between U.S. and Japanese housing (construction techniques aside) is the amount of space available per home and per resident. ${ }^{(a)}$ According to Table 3.2, the average floor space per house in the U.S. is nearly twice that in Japan. Given the larger household size in Japan, the amount of living space per person in Japan is smaller still.

\footnotetext{
(a) Differences in the type of heating ventilation, refrigeration and air conditioning equipment are not considered in this analysis. Japanese residences primaxily use zone heating (such as portable kerosene heaters), although there is some movement towards central heating systems, which predominate in the U.S. Also, differences probably exist in the size, numbers, and type of energy-consuming appliances (such as dishwashers, water heaters, and refrigerators) between the U.S. and Japan.
}

Average living space per person was derived by dividing the average floor space per home by the a"erage number of persons per home. This measure was thought to be most comparable, but only if the U.S. and Japanese data sources agree on the definitions of "home" (primary residence, includes all types of homes, such as apartments, town houses, in addition to single-family homes) and "floor space" (bedrooms, hallways, kitchens, closets, etc.).

One Japanese data source also provided data for average floor space per "dwelling" which was significantly smaller ( $41.7 \mathrm{~m}^{2}$ ) (Japan Statistics Bureau 1986). It is not clear whether this definition of "dwelling space" includes hallways, bathrooms, and other areas that would be included in a definition of total floor space in the U.S.

\subsection{COMMERCIAL BUILDING CHARACTERISTICS}

Survey data were obtained for detailed energy consumption and characteristics of commercial buildings: 1983 data for the U.S. (DOE-EIA 1986) and 1985 data for Japan (JIEE 1987). Because the data are survey data, the years of the survey differ; and because building classifications schemes are not compatible between the U.S. and Japan, comprehensive comparisons of buildings types and energy consumption are not possible. However, direct comparisons of energy consumption per square meter of floor space for some building types are presented in Section 3.5.

\subsection{ENERGY CONSUMPTION IN THE RESIDENTLAL AND COMMERCIAL SECTOR}

As was shown in Table 2.1, total energy consumption in the residential and commercial sector varies greatly between the U.S. and Japan. A discrepancy also exists in the reported values between domestic and international sources of data. These data are presented again in Table 3.3, with a separate breakdown for the residential sector and the commercial sector.

As Table 3.3 shows, when considering IEA data sources, U.S. residential and commercial energy use is over seven times that of Japan. However, if domestic data sources are used, it is less than six 
Table 3.2. Housing Characteristics in the U.S. and Japan (1985, except when year reported in parentheses) (a)

\begin{tabular}{|c|c|c|c|}
\hline & U.S. & Japart & U.S./Japan \\
\hline Number of households (million) & 86.8 & 36.6 & 2.4 \\
\hline Average number of persons per household & 2.7 & 3.1 & 0.9 \\
\hline Average living space per person $\left(\mathrm{m}^{2}\right)$ & $\begin{array}{r}57.5 \\
(184)\end{array}$ & $\begin{array}{r}27.7 \\
(183)\end{array}$ & 2.1 \\
\hline Hor.a ownershlp rates & $\begin{array}{r}64.7 \\
(\cdot 83)\end{array}$ & $\begin{array}{r}62.4 \\
(183)\end{array}$ & 1.0 \\
\hline Average number of roonis per home & $\left(\begin{array}{l}5.1 \\
(.83)\end{array}\right.$ & $\begin{array}{r}4.7 \\
(.83)\end{array}$ & 1.1 \\
\hline Average floor space of new homeg $\left(\mathrm{m}^{2}\right)$ & $\begin{array}{l}134.8 \\
(\cdot 84)\end{array}$ & $\begin{array}{r}83.4 \\
(185)\end{array}$ & 1.6 \\
\hline $\begin{array}{l}\text { Average } f l o o r \text { apace per home }\left(\mathrm{m}^{2}\right) \\
\text { (all homes) }\end{array}$ & $\begin{array}{l}155.3 \\
(\cdot 84)\end{array}$ & $\begin{array}{r}85.9 \\
(.83)\end{array}$ & 1.8 \\
\hline Average floor space per dwelling $\left(\mathrm{m}^{2}\right)^{(b)}$ & $-\infty$ & $\begin{array}{r}41.7 \\
(.83)\end{array}$ & -- \\
\hline
\end{tabular}

(a) Sources: Japan Economic Planning Agency 1988, 1987; Japan Statistics Bureau 1988, 1986; DOC 1987a; DOE-EIA 1987a.

(b) This might not include hallways, closets, etc. No comparable U.s. data.

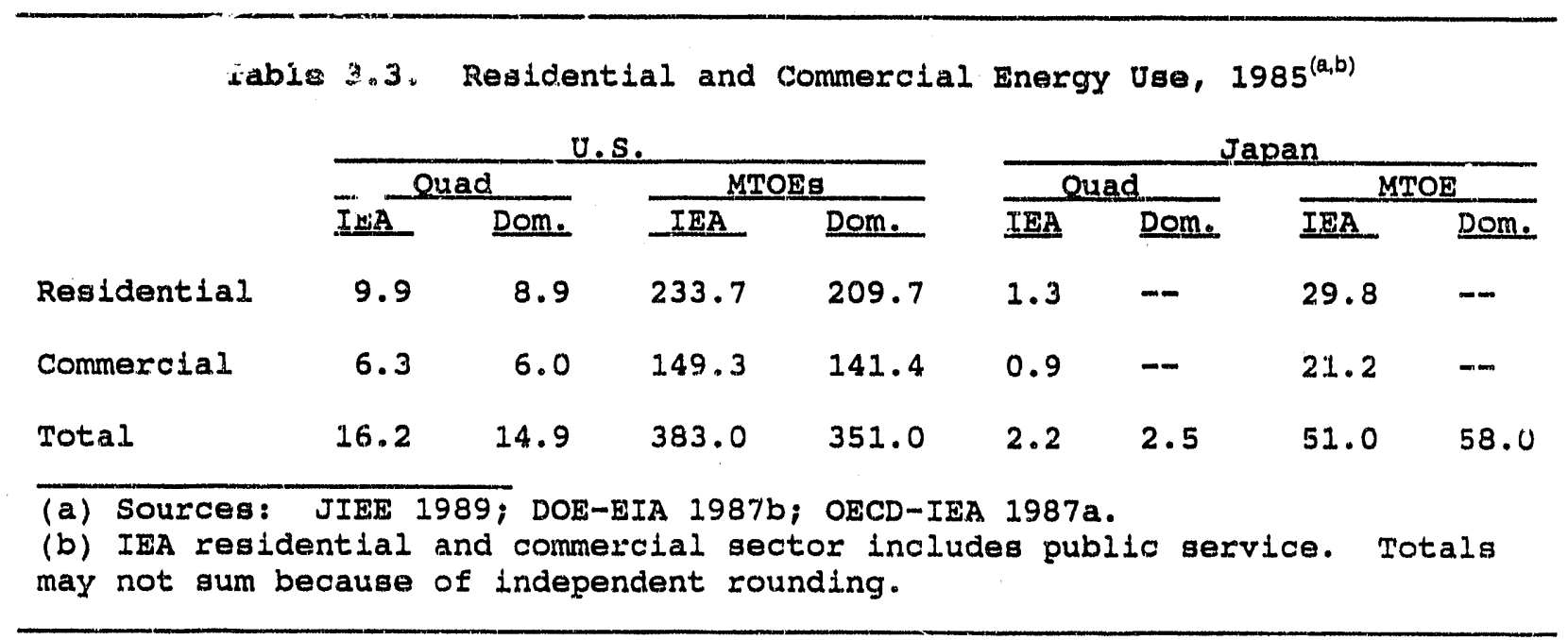


times as great. Residential energy consumption in the U.S. exceeds commercial energy consumption using either the IEA or domestic data source. In Japan, residential energy use also exceeds commercial energy use, according to IEA data. No domestic data were obtainable to establish a breakdown between residential and commercial energy consumption in Japan.

Comparative studies have been made of residential energy use in OECD countries (Schipper and Ketoff 1985). These studies have included detailed analysis of the residential sector in the U.S. and Japan (Schipper and Ketoff 1983). This latter study in particular provided energy use for a variety of residential purposes. This study showed that the larg. est single use of energy for residential purposes in the U.S. is for space heating. Energy use for space heating in Japan, on the other hand, lagged slightly behind water heating. In addition, the greatest difference in energy consumption pe: dwelling between the U.S. and Japan was for space heating purposes. Energy use as a function of floor space and outdoor temperature is the primary focus in the following section.

\subsection{ENERGY INTENSITY IN THE RESIDENTIAL AND COMMERCIAL SECTOR}

Some relative measures of energy intensity can be developed using data presented in the previous sections. Table 3.4 is such an attempt for the residential sector. IEA and domestic energy data sources are used for the U.S., while just IEA data are used for Japan.

The metrics used in 'Table 3.4 can be somewhat confusing but are necessary, given available data. Energy use per household and per HDD are rather straightforward. Both measures show the U.S. to be much more energy-intensive than Japan.

The next two measures show energy use per square meter of living space either per dwelling or per person. Because the total amount of residential living space is unknown (although an approximation could be made by multiplying average living space per dwelling by the number of dwellings), this convention was kept. Both measures narrow the gap between U.S. and Japanese energy intensity in the residential sector.

The final metric is an attempt to allow for both living space per person and the difference in HDDs. Both upper and lower bounds are shown for this measure, necessitated by the upper and lower bounds for HDDs for Japan. As the table shows, this measure portrays the U.S. as being about twice as energy-intensive in the residential sector as Japan.

Table 3.5 presents energy intensity data for the commercial sector for five building types: education, health care, lodging, retail/wholesale, and offices. The data are in Mcal per square meter of building space. The data for Japan are also adjusted to allow for the relative difference in the number of HDDs between the U.S. and Japan (both upper and lower bound).

Caution should be used in drawing conclusions from commercial building energy use weighted solely by climate. Energy use for space heating, which is climate related, is not the dominant use of energy in many commercial building types. Energy use for lighting, for instance, is important in commercial office buildings. Also important to an analysis of this sort is the worker or occupant density of a building; however, comparable data for that were not obtainable.

Using data that are not adjusted by climate (HDD), all building types in the U.S except lodgings consume more energy per square meter in the U.S. than Japan. If the data are adjusted for HDDs, the U.S. compares more favorably with Japan. For instance, if the upper bound (cold winter in Japan) estimate is used for Japan, lodgings and health care facilities in the U.S. appear less energy-intensive than their Japanese counterparts. If the lower bound (mild winter in Japan) is used, all U.S. commercial building types are less energy-intensive than Japan. 
Table 3.4. Residential Energy Intensity Measures, $1985^{(a)}$

$\frac{\text { U.S. }}{\text { IEA }} \frac{\text { Japan }}{\text { IEA }}$

TOEs per

Household

$\begin{array}{lll}2.7 & 2.4 & 0.8\end{array}$

Thousands of TOEs

per EUD

Upper Bound

Lower Bound

$49.0 \quad 43.9 \quad 8.5$

$49.0 \quad 43.9 \quad 14.3$

MTOBa per $\mathrm{m}^{3}$ of Living space

1.5

1.4

0.3

per Dwelling

\section{MTOEs per $\mathrm{m}^{2}$} of Iiving space

per Person

Mroba per $\mathrm{m}^{2}$

of Living space

per Peruon per HDD

Uppir Bound

Lower Bound

$\begin{array}{lll}0.9 & 0.8 & 0.3 \\ 0.9 & 0.8 & 0.5\end{array}$

(a) Sources: JIEE 1989; Japan Economic Planning Agency 1988; Japanese Statiot16s Bureau 1988; DOC 1987a; DOE-EIA 1987a, 1987b; NOAA 1987a, 1987b; OZCD-IEA 1987a; Climate Dictionary 1986.

Table 3.5. Comercial Energy Intensity (Mcal per meter $\left.{ }^{2}\right)^{(a)}$

\begin{tabular}{|c|c|c|c|c|}
\hline & & & n 119 & \\
\hline & u.s. & & Adju & HDDB \\
\hline & (1983) & Onadjusted & UB & LE \\
\hline Education & 217.2 & 103.0 & 140.2 & 235.1 \\
\hline Heaith Care & 553.0 & 426.4 & 580.2 & 973.1 \\
\hline Lodging & 442.5 & 497.2 & 676.6 & 1134.7 \\
\hline Retail/Wholeale & 426.2 & 279.4 & 380.2 & 637.6 \\
\hline Office & 333.9 & 217.9 & 296.5 & 497.3 \\
\hline
\end{tabular}

(a) Sources: Amole et al. 1988; JIEE 1987; DOE-EIA 1986. 


\subsection{TRANSPORTATION SECTOR}

Transportation energy consumption does not depend solely on how much energy is consumed per kilometer for a particular transportation mode. Even more important than the relative energy iff ficiency of the various means of travel may be the mode of travel (Section 4.1) and the number of vehicle miles travelled (Section 4.2). These arcas are discussed below as well as energy use (Section 4.3) and intensity (Section 4.4) for the transportation sector.

\subsection{MODE OF TRAVEL}

Usually several choices of mode of travel are available for either people or cargo. The modes of travel considered in this report are car, bus, rail, and air for passengers; ${ }^{(a)}$ and trick, rail, air, and ship for cargo. Pipeline, an imporiant means of transport in the U.S., is rot considered because pipeline data could not be obtained for Japan.

\subsubsection{Passenger}

Perhaps the starkest difference in travel patterns between the U.S. and Japan is in use of passenger automobile travel. Table 4.1 shows passenger travel in passenger-kilometers (P-km) (the number of persons traveling per kilometer by each mode) for the U.S. and Japan. As the table shows, nearly $90 \%$ of U.S. passenger travel is by private automobile. ${ }^{(b)}$ In contrast, less than $45 \%$ of Japanese passenger miles are logged in i.utomobiles.

While second to automobile transport, passenger rail is highly significant in Japan (38.5\%). In fact, passenger rail travel $\left(330.1 \times 10^{9} \mathrm{P}-\mathrm{km}\right)$ in Japan is nearly ten times that in the U.S. $\left(35.6 \times 10^{9} \mathrm{P}-\mathrm{km}\right)$, but Japan has one-half the population of the U.S. Bus travel is also more significant in Japan (12.2\%) than in the U.S. $(2.9 \%)$.

(a) Some data are also presented on passenger travel in Japan by ship.

(b) Includes light trucks, which are increasingly popular in the U.S.; motoreycles not included for U.S. or Japan.
Given only the data in Table 4.1, it would appear that the U.S. probably consumes more energy per $P-k m$ traveled than Japan because automobile and air travel consume far more energy per P-km then either bus or rail. This assumes, of course, that buses and trains carry enough passengers to offset the higher energy cost per kiloneter of traveling in this manner.

As Table 4.1 shows, the average travei per person in the U.S. in 1985 was over 21,000 kilometers, while Iapan had one-third as much (about 7,000 kilometers). This difference alone helps to explain a large part of the eight-fold difference in passenger transportation energy consumptinn between the U.S. and Japan.

\subsubsection{Freight}

Several choices of mode of travel for freight are available. Table 4.2 shows tonnes of freight movement per kilometer (T-km) in the U.S. and Japan. As the table shows, the U.S. moves the bulk of its cargo by rail, usually the least energy-intensive form of movement. Japan, on the other hand, relies heavily on truck and ship movement. The U.S. also relies heavily on pipeline for movement of crude oil and petroleum products, as well as natural gas. However, as noted earlier, because pipeline data were not available for Japan, this particular mode of transport is not included in the analysis.

\subsection{VEHICLE KILOMETERS TRAVELED}

To determine the amount of energy consumed per kilometer traveled, both total energy consumption and total vehicle-kilometers (V-km) traveled must be known. A V-km is the distance traveled by a particular type of vehicle (e.g., car, bus, and train). Vehicle-kilometers do not concern the amount of freight or passengers carried, just the distance traveled by the vehicle under consideration. Data for V-km traveled are shown in Table 4.3.

As Table 4.3 shows, automobiles travel the greatest number of kilometers in both the U.S. (75.4\%) 
Table 4.1. Passengex Travel by Mode, $1985\left(10^{9} \mathrm{P}-\mathrm{km}\right)^{(a, b, c)}$

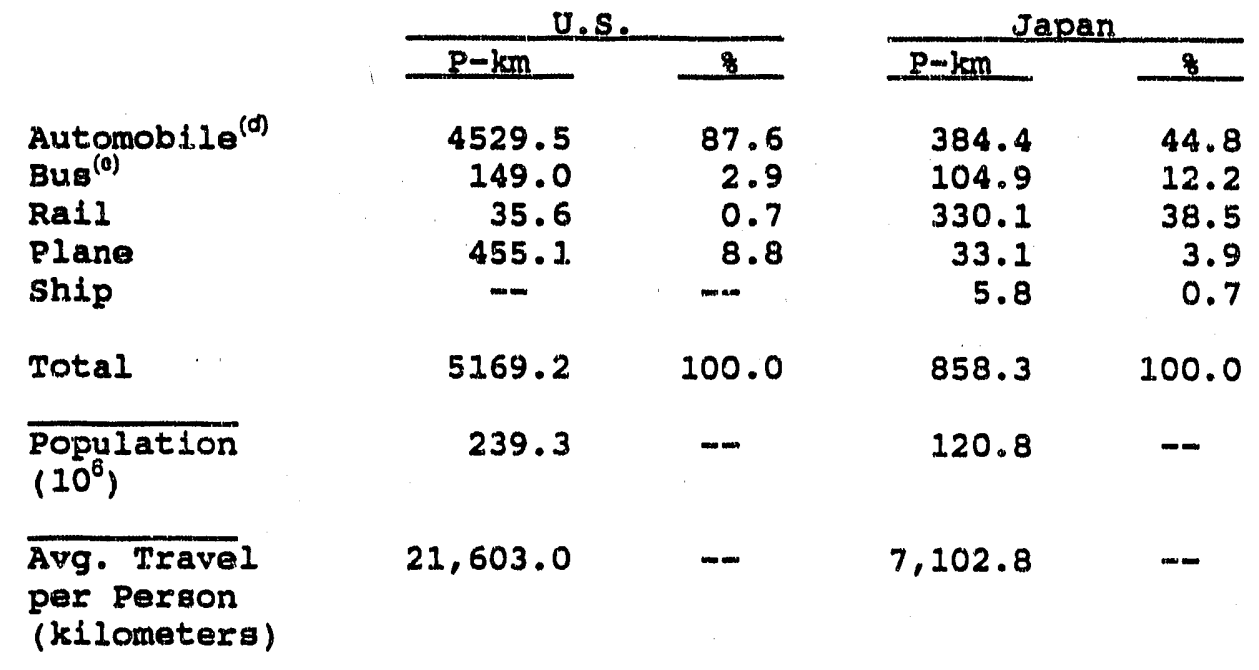

(a) Sourcez: Japan Ministry of Transport 1988; U.S. Department of Transportation (DOT) 1987.

(b) Also, Davis, s. C., et al. 1988 (draft). 1988 Aufomated

Transportation Energy Data Book. Oak Ridge National Laboratory,

Oak Ridge, Tennessee.

(c) Totals may not sum because of independent rounding.

(d) Does not include 2-wheel vehicles (mivtorcycles). U.S. data include light trucks.

(e) U.S. includes school buses.

Table 4.2. Freight Movement by Mode, $1985\left(10^{9} \mathrm{~T}-\mathrm{km}\right)^{(\mathrm{a}, \mathrm{b})}$

\begin{tabular}{lrrrrr} 
& \multicolumn{2}{c}{ U.S. } & & \multicolumn{2}{c}{ Japan } \\
\cline { 2 - 3 } Truck & 890.6 & 32.2 & 205.9 & 47.4 \\
Rail & $1,306.7$ & 47.3 & 22.1 & 5.1 \\
Plane & 9.8 & 0.4 & 0.5 & 0.1 \\
Ship & 557.7 & 20.2 & 205.8 & 47.4 \\
Total & $2,764.8$ & 100.0 & 434.3 & 100.0
\end{tabular}

(a) Sources: DOC 1987a: Japan Ministry of Transport 1987.

(b) Totals may not sum because of independen.

rounding. Original U.S. data included pipeline

transportation but are not included here. 


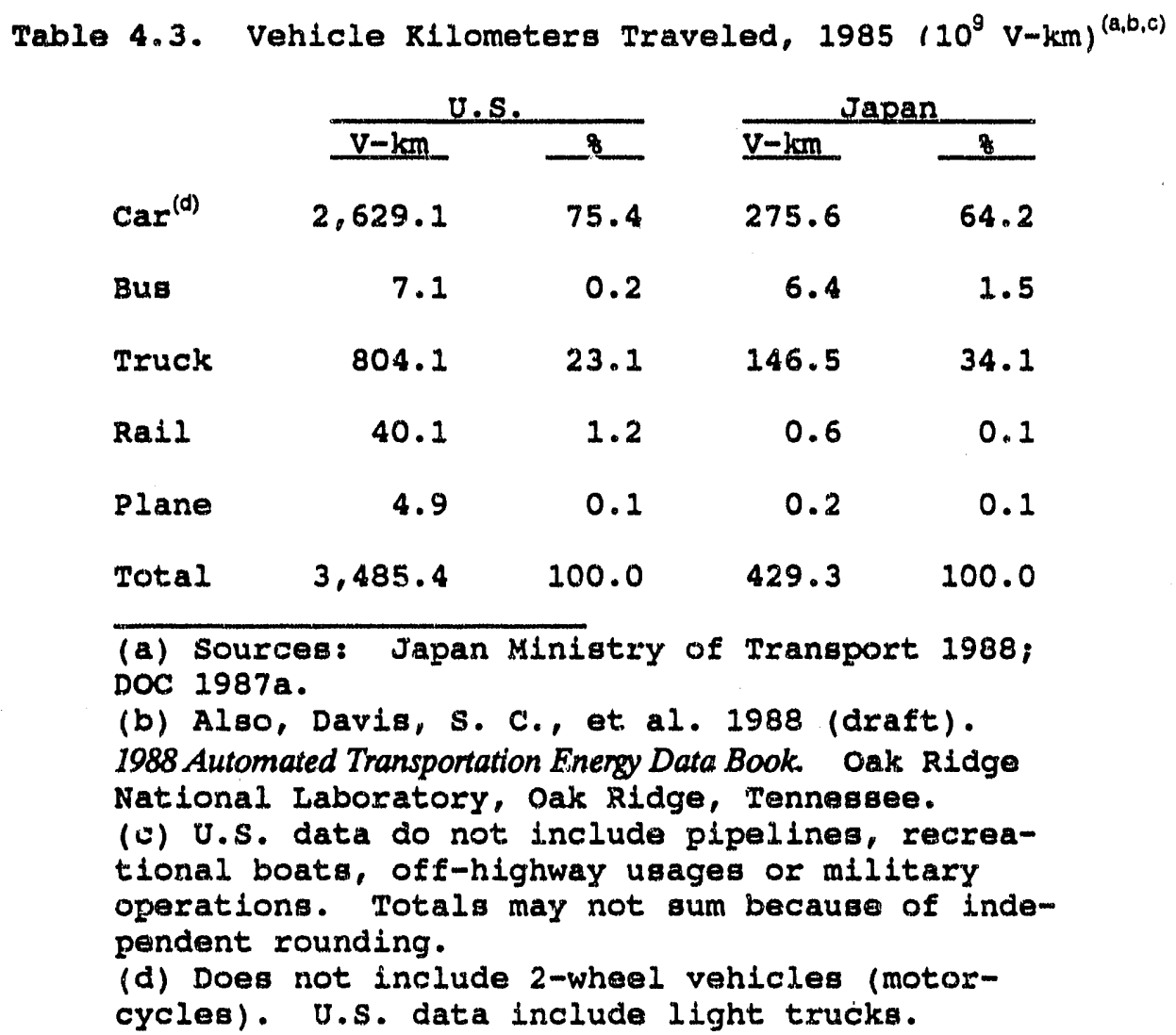

and $\mathrm{Ja}_{1}$,an (64.2\%). Trucks rank second in both countries as well. Unexpected results in this table are the relatively few kilometers logged by both buses and trains in Japan. Given the relatively large number of passenger-kilometers logged by these means of transport, capacity factors in Japan must be quite high. ${ }^{(k)}$

Estimates of capacity factors can be derived by dividing the total amount of P-km or T-km by the $\mathrm{V}-\mathrm{km}$ traveled for the appropriate mode. These data are shown in Table 4.4. Freight and passenger transport could not be distinguished by either rail or plane. Data for ship-kilometers traveled were not available.

As Table 4.4 shows, more passengers travel per car per kilometer in the U.S. (1.7) than Japan (1.4).

(a) However, it is believed that the relatively low number of train-kilometers logged may be an artifact of data collection, as discussed in Section 4.4.
On the other hand, Japan has more passengers traveling by bus per kilometer (16.5) than the U.S. (15.8). Trucks in Japan carry more tonnes of freight per kilometer than their U.S. counterparts.

\subsection{TRANSPORTATION ENERGY USE}

Data for transportation energy use presented in Table 2.1 again appear in Table 4.5. Total transportation energy use as reported by either the IEA or domestic energy sources is reasonably close. Energy consumption for U.S. transportation is about ten times greater than that of Japan.

Table 4.6 shows transportation energy use by mode for both passenger and freight travel. The table shows that cars, followed by trucks, are the number one and two consumers of energy in both the U.S. and Japan. However, whereas ships are the next largest consumer of energy in Japan, ships rank last in the U.S. after planes, trains, and buses. In 


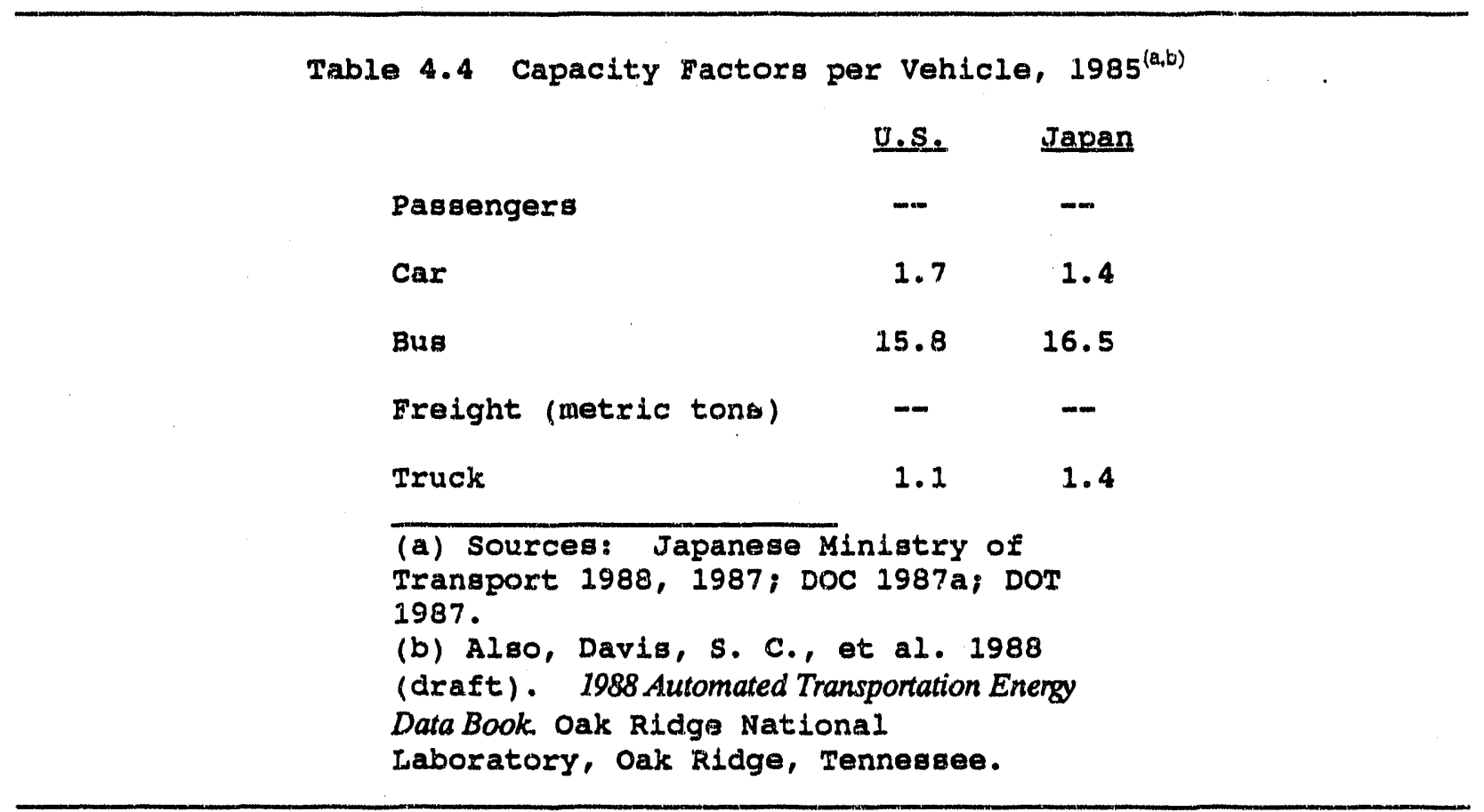

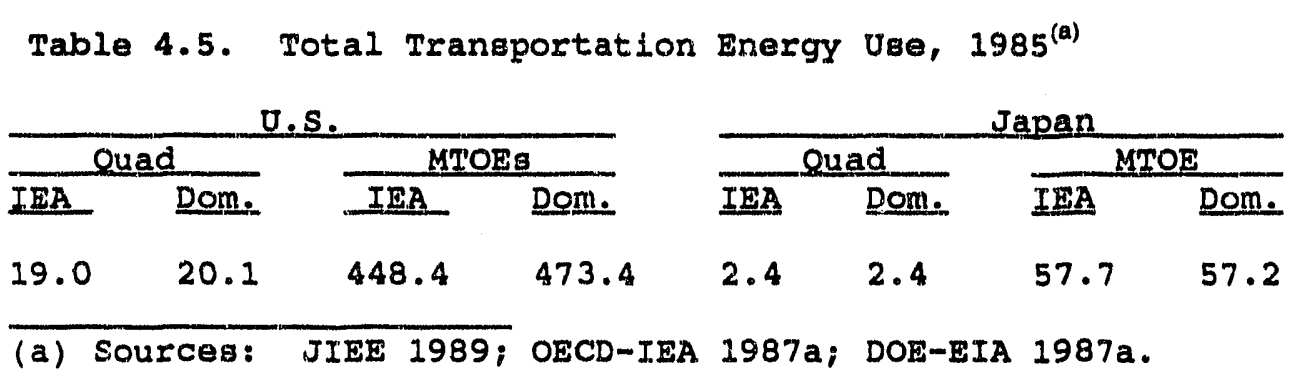

Japan, air travel ranks nearly last in energy consumption among the various travel modes.

The totals for energy consumption in Table 4.6 are less than reported in Table 4.5, particularly for the U.S., probably because U.S. totals do not include pleasure boating or pipeline transportation energy use, as noted in Table 4.6. If these two energy uses were included, the U.S. total in Table 4.6 would rise to 440.2 MTOEs.

\subsection{TRANSPORTATION ENERGY INTENSITY}

Energy intensity measures can be dexived by type of travel (passenger, freight, or vehicle) and mode. Table 4.7 presents energy intensity by passenger, freight, and vehicle travel and by each mode of travel. The units for the table are TOEs per $10^{6}$ kilometers traveled. That is, the larger the number in Table 4.6, the greatic amount of energy required to provide the same level of service. The relative 
Table 4.6. Transportation Energy Use by Mode, 1985 (MTOE) (a,b,c) $^{(2, a)}$

\begin{tabular}{|c|c|c|c|c|c|c|}
\hline & \multicolumn{3}{|c|}{ U.S. } & \multicolumn{3}{|c|}{ Japan } \\
\hline & Pagsenger & Freight & Total & Pagsenger & Frelght & Total \\
\hline $\operatorname{Cax}^{(d)}$ & 276.7 & -- & 276.7 & 25.0 & - & 25.0 \\
\hline Bus & 3.8 & -- & 3.8 & 1.5 & - & 1.5 \\
\hline Truck & -- & 81.0 & 81.0 & -- & 21.4 & 21.4 \\
\hline Rail & 1.6 & 10.1 & 11.7 & 1.6 & 0.6 & 2.2 \\
\hline Plane & 35.6 & -- & 35.6 & 2.1 & - & 2.1 \\
\hline Ship & -- & 9.4 & $9.4^{(\theta)}$ & 0.02 & 4.7 & 4.7 \\
\hline Total & 317.7 & 100.5 & $418.1^{(n)}$ & 30.2 & 26.7 & 56.9 \\
\hline
\end{tabular}

(a) SOurce: JIEE 1987.

(b) Also, Davis, S. C., et al. 1988 (draft). 1988 Automated Transportation Energy

Data Book. Oak Ridge National Laboratory, Oak Ridge, Tennessee.

(c) Totals may not sum becauge of independent rounding.

(d) Does not include 2-wheel vehicles (motorcycles). U.S. includes light trucks.

(e) Ship travel does not include pleasure boating, which totaled 0.229 quad (5.4 MTOEa) for the U.S. in 1985.

(f) Pipeline data for the U.S., although very significant, axe not included because similar data were not available for Japan. U.S. pipeline energy use in 1985 was 0.708 guad (16.7 MTOEs).

efficiency of both P-km and T-km will be affected by the energy efficiency of the vehicle providing the service and by the vehicle's capacity factor (e.g, number of passengers per car or tonnes of freight per truck).

As Table 4.7 shows, the U.S. (61.1) consumes less energy to carry the same number of persons by car than Japan (65.0). Passenger rail travel is the most energy efficient means of travel in Japan, about one-tenth of the energy consumed per P- $\mathrm{km}$ for passenger rail service in the U.S. Overall, about one-half the energy is required to move people (1 person $1 \mathrm{~km}$ ) in Japan (35.2) as in the U.S. (61.9).

This raises the question as to whether the lesser energy intensity of passenger travel in Japan is the result of better energy efficiency of passenger transportation vehicles or the mode-choice (choice of travel modes). This can be examined by holding vehicle energy intensities constant while redistributing total Japanese passenger travel to match modechoice patterns in the U.S. (i.e., more car travel). If Japanese travel habits were similar to those in the U.S., Japanese passenger energy intensity would rise to $63.1 \times$ TOEs per $10^{6} \mathrm{P}-\mathrm{km}$, or slightly greater than that in the U.S. (61.9).

Total froight energy intensity for the U.S. (36.5 $\mathrm{x}$ TOE per $10^{6} \mathrm{~T}-\mathrm{km}$ ) compares favorably with Japan (61.6). All modes of freight transport in the U.S. are less energy-intensive in terms of energy consumption per tonnes of cargo moved than in Japan. This may be a result of the (U.S.) long-haul versus (Japan) short-haul phenomena in trains, and Japan's relatively greater use of trucks in the urban environment, as opposed to the U.S.'s interstate highway use. As in the above analysis, "if" the Japanese were to move freight "like" the U.S., overall Japanese freight energy intensity would fall to $46.3 \times$ TOEs per $10^{6} \mathrm{~T}-\mathrm{km}$. This is a result of movement away from ship and towards rail transport.

When considering only vehicle movement, U.S. (105.3) cars consume more erergy per kilometer traveled (fewer miles per gallon) than Japan (90.7). Likewise, U.S. buses consume over twice as much energy per kilometer traveled compared with Japan. However, U.S. trucks, airplanes, and in particular, 


\begin{tabular}{|c|c|c|c|c|c|c|}
\hline \multirow[b]{2}{*}{ Mode } & \multirow{2}{*}{\multicolumn{3}{|c|}{$\begin{array}{ccc}\text { Table 4.7. } & \begin{array}{l}\text { Transportation Ene } \\
\text { (TOE per } 10^{6} \mathrm{P}-\mathrm{km},\end{array} \\
& \text { U.S. } \\
\text { Pass. } & \text { Freight } & \text { Veh. }\end{array}$}} & \multicolumn{2}{|c|}{$\begin{array}{c}\text { gy Intengity by Mode, } \\
\mathrm{c}-\mathrm{km} \text {, or } \mathrm{v}-\mathrm{km})(\mathrm{a}, \mathrm{b}, \mathrm{c}) \\
\text { Japan }\end{array}$} & 1985 \\
\hline & & & & $\begin{array}{l}\text { Pass. } \\
(\mathrm{E} / \mathrm{P}-\mathrm{km})\end{array}$ & $\begin{array}{l}\text { Freight } \\
(\mathrm{E} / \mathrm{T}=\mathrm{km})\end{array}$ & $\begin{array}{c}\text { Veh. } \\
(\mathrm{E} /(\mathrm{V}-\mathrm{km})\end{array}$ \\
\hline $\begin{array}{l}\operatorname{Car}^{(d)} \\
\text { Bus } \\
\text { Truck } \\
\text { Rail } \\
\text { Plane } \\
\text { Ship }\end{array}$ & $\begin{array}{l}61.1 \\
25.4 \\
-- \\
44.3 \\
78.2 \\
-\infty\end{array}$ & $\begin{array}{l}-- \\
-30.9 \\
7.7 \\
-- \\
16.8\end{array}$ & $\begin{array}{r}105.3 \\
530.4 \\
100.7 \\
290.4 \\
7,255.4 \\
-\end{array}$ & $\begin{array}{r}65.0 \\
14.0 \\
-3 \\
4.9 \\
62.5 \\
2.9\end{array}$ & $\begin{array}{c}-- \\
\overline{104.2} \\
26.8 \\
\overline{22.8}\end{array}$ & $\begin{array}{r}90.7 \\
232.0 \\
146.4 \\
3,563.1 \\
8,952.0 \\
\ldots\end{array}$ \\
\hline Total & 61.5 & 36.5 & 117.3 & 35.2 & 61.6 & 121.6 \\
\hline $\begin{array}{l}\text { (a) Sourc } \\
\text { JIgE } 1987 \\
\text { (b) Also, } \\
\text { Data Book. } \\
\text { (c) Tota } \\
\text { include } \\
\text { oignifice } \\
\text { Japan. } \\
\text { (d) Does } \\
\text { (e) U.S. }\end{array}$ & $\begin{array}{l}\text { ces: Japar } \\
7 . \\
\text {, Davis, s } \\
\text { Oak Ridge } \\
\text { ls may not } \\
\text { pleasure bc } \\
\text { ant, are no } \\
\text { not inclus } \\
\text { includes }\end{array}$ & $\begin{array}{l}\text { Ministry } \\
\text { c., et al } \\
\text { National } \\
\text { sum becaus } \\
\text { bating. P1 } \\
\text { t Included } \\
\text { de 2-wheel } \\
\text { chool buse }\end{array}$ & $\begin{array}{l}\text { Transpor } \\
1988 \text { (dra } \\
\text { aboratory, } \\
\text { of indepe } \\
\text { peline data } \\
\text { because } 81 \\
\text { rehicles (m } \\
\text {. }\end{array}$ & $\begin{array}{l}1988,198 \\
\text { t). } 1988 \mathrm{~A} \\
\text { Oak Ridge, } \\
\text { dent round } \\
\text { for the U. } \\
\text { iliar data } \\
\text { torcycles) }\end{array}$ & $\begin{array}{l}\text { 7; Doc } 1987 \\
\text { tomated Transp } \\
\text { Tennessee. } \\
\text { ing. Ship } \\
\text { s. althoug } \\
\text { were not av }\end{array}$ & $\begin{array}{l}\text {; DOT 1987; } \\
\text { ortation Energy } \\
\text { travel does } \\
\text { very } \\
\text { ailable for }\end{array}$ \\
\hline
\end{tabular}

trains consume less energy.(s) Overall, the U.S. (117.3) is slightly less energy-intensive than Japan (121.6) in terms of energy consumed per kilometer for all vehicular travel. ${ }^{(b)}$

(a) The difference in energy consumption for trains is so great as to raise the question of the reliability of this data. The difference may be a result of the way in which "trains" are counted. In the U.S., each railroad car counts as a separate vehicle. Therefore, a nine-car train (plus the engine) traveling one kilometer would count as ten train-kilometers. It may be that the Japanese only count the engine, which would tend to greatly understate the train-kilometers and therefore greatly increase the energy inten sisy

(b) The comparison of total vehicular energy intensity might be distorted by the Japariese definition of "train-kilometers," as already noted. 


\subsection{INDUSTRIAL SECTOR}

The analysis of energy intensity in the industrial sector is primarily focused on the manufacturing industries. Section 5.1 attempts to provide a consistent definition for the manufacturing sector between the U.S. and Japan. Section 5.? details energy use in the industrial sector, while Section 5.3 discusses measures of activity in manufacturing. Finally, Section 5.4 analyzes manufacturing energy intensity.

\subsection{DEFINING THE INDUSTRIAL SECTOR}

To provide a true comparison of energy intensity in the industrial sector for the U.S. and Japan, industries that compose this sector must be defined consistently. At the first level of disaggregation, the industrial sector in both countries is comprised of agriculture, construction, mining and quarrying, and manufacturing industries. Beyond this, the classification schemes of the two countries differ to a certain extent.

The U.S. uses the DOC's Standard Industrial Classification (SIC) system to classify industries. Japan's classification scheme is known as the Japanese Standard Industrial Classification (JSIC) system. To further complicate matters, the IEA uses the International Standard Industrial Classification (ISIC) system. ${ }^{\left({ }^{()}\right.}$

Tables 5.1 and 5.2 provide correspondence between these various classification schemes. Table 5.1 uses U.S. SIC codes as the baseline definition and shows corresponding JSIC and ISIC classification codes. Table 5.2, on the other hand, begins with international definitions of industries and shows how U.S. and Japanese classification systems collapse into this broader classification scheme.

Where possible, this analysis uses the highest level of industry detail, which is determined primarily by the availability of energy consumption data. The most detail is provided when domestic sources of energy are compared. When IEA data are compared with domestic data, much detail is lost because of incompatibility in industry definitions.

(a) Three-digit ISIC codes are essentially equivalent to two-digit SIC and JSIC codes.
Even the level of detail used here is so aggregate as to cloud the analysis of these industries. Actual energy intensity involves the "mix" of products being produced. Although not all products in an industry, such as chemicals, can be accounted for, some of the product mix in industries is discemible, such as primary metals and paper, pulp, and printing. The analysis of energy intensity for these larger industry definitions will be less valid to the extent that the product mix varies between these two countries, particularly when that mix impacts energy requirements.

\subsection{INDUSTRIAL ENERGY CONSUMPTION}

The industrial sector consists of the agriculture, construction, mining and quarrying, and manufacturing industries. Table 5.3 shows energy consumption by these subsectors including non-energy use of fuels. As the table shows, the manufacturing industries account for most of the energy consumption in the industrial sector. Given the relative importance of manufacturing and the lack of data for these other industries, this analysis is focused towards manufacturing.

Table 5.3 shows that there is not a good correspondence between energy consumption data for the IEA and domestic data sources, particularly for Japan's manufacturing energy consumption. The difference between IEA (114.9 MTOEs) and domestic (194.3 MTOEs) data for manufacturing energy consumption is partly because the domestic data source includes non-energy use of fucls while the IEA does not. However, even after including non-energy use (all industry) of 7.7 MTOEs, a substantial difference still remains between these data. Although some attempt is made to resolve this difference, it is largely beyond the scope of this paper.

Both domestic and IEA data are used to analyze manufacturing energy consumption and intensity in the U.S. and Japan. Given that domestic sources for energy consumption for both countries include nonfuel use, the comparison should be more valid. However, energy intensity data are also presented using IEA data, although industry detail will have to 


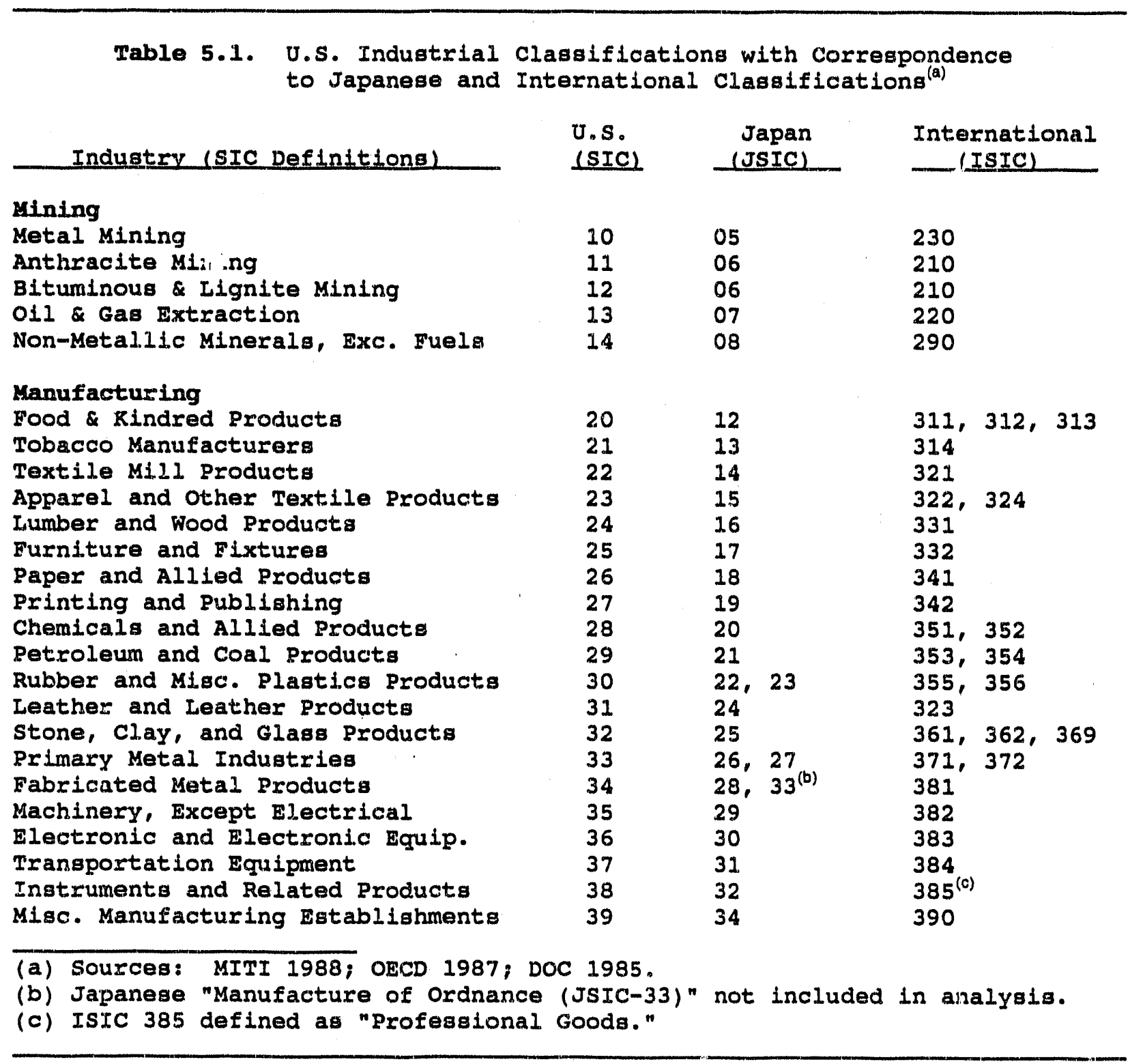

decrease as already noted. In the following subsections, manufacturing energy consumption is discussed for each country, followed by a comparison of the data for each.

\subsubsection{U.S. Manufacturing Energy Consumption}

In the past, the primary source for data on energy consumption in the manufacturing sector was a supplementary survey to the Annual Survey of Manufacturer (ASM). This energy survey was not comprehensive in that it only included data on purchased energy and did not include internally generated power (DOC 1982). The supplemental survey ended in 1982.

Fortunately, the DOE-EIA (1988) initiated a new Manufacturing Energy Consumption Survey (MECS) beginning with data for 1985 . Table 5.4 presents this data by industry in the original units (Btu) and MTOEs. The 17.5 quad (413.0 MTOE) of energy reported in Table 5.4 includes all fiesl use, whether for energy or feedstocks. 
Table 5.2. Relation of ISIC, SIC, JSIC Clasaificationg(a)

Industry (ISIC Definitions)

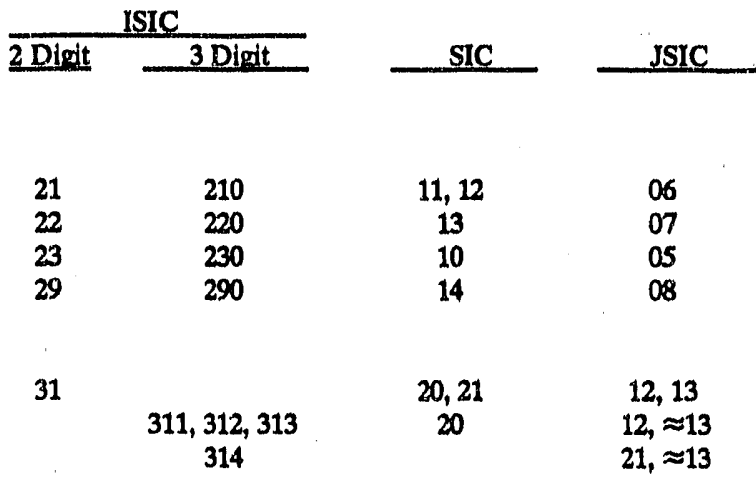

Noning

Coal Mining

Crude Petroleum and Natural Gas Prod.

Metal Ore Mining

Other Mining

314

32

Textile, Wearing Apoarel and Leather Ind.

Textiles

Wearing apparel, except footwear

Leather and products of leather

Footwear (except rubber or plastic)

Wood and Products, including Fumiture

Wood and wood and cork products

Furniture and fixtures

Paper and Prod. Printing and Publishing

Paper and paper products

Print, publishing and allied industries

Chem. Pet. Coal, Rub. and Plastic Prod.

Industrial chemicals and chemical Prod.

Pet. refineries and prod. of pet. and coal

Rubber and plastic products

Non-Metal. Min. except Pet. and Coal Prod.

Basic Metal Industries

Iron and steel

Non-ferrous

Manufacture of Pabricated Metal Prod.

Fabricated metal products

Machinery, except electrical

Electrical machinery apparatus

Transportation equipment

Prof. and scientific measurement equip.

Other Manufacturing Industries

\section{1 \\ 322 \\ 323 \\ 324}

33

331

332

34

341
342

35

351, 352

353,354

355,356

36

37

371

372

38

381
382
383
384
385

390
22, 23, 31

22
23
31

31

24,25
24

24

26,27
26

27

$28,29,30$

28
29

30

32

33

331,332

333-336, 339

$34-38$
34
35
36
37
38
39

$14,15,24$

14

$\approx 15$

$\approx 24$

$\approx 15, \approx 24$

16,17

16

17

18,19

18

19

$20,21,22,23$

20
21

22,23

25

26,27

26

27

28-32

$28,33^{(b)}$

29

30

31

32

34

(a) Sources: MrTI 1988; OECD 1987; DOC 1985.

(b) Japanese "Mauufacture of Ordnance (JSIC-33)" not included in analysis.

If non-energy use of fuels is excluded, manufacturing energy consumption as reported by MECS would total just 13.6 quad (320.4 MTOEs). If nonenergy use of fuels (40.1. MTOEs) and agricultural energy use (13.2 MTOEs) are removed from the
IEA total, industrial energy use would be just 392.6 MTOEs or a difference in MECS and IEA data sources of 72.2 MTOEs (3.1 quad). This IEA total still includes the construction, and mining and quarrying industries, however. 
Table 5.3. Industrial Energy Consumption, $1985^{(a, b)}$

\begin{tabular}{|c|c|c|c|c|c|c|c|c|}
\hline & \multicolumn{4}{|c|}{ U.S. } & \multicolumn{4}{|c|}{ Japan } \\
\hline & \multicolumn{2}{|c|}{ Quad } & \multicolumn{2}{|c|}{ MTOES } & \multicolumn{2}{|c|}{ Quad } & \multicolumn{2}{|c|}{ MTOEg } \\
\hline & Dom. & IFA & Dom. & IEA & Dom. & IEA & Dom. & IEA \\
\hline Agriculture & - & 0.6 & - & 13.2 & 0.2 & 0.2 & 3.8 & 3.9 \\
\hline Mining and Quarry & -- & $-\infty$ & $-m$ & $-\infty$ & 0.01 & 0.06 & 0.3 & 0.3 \\
\hline Congtruetion & $-\infty$ & - & - & - & 0.1 & 0.2 & 1.5 & 4.0 \\
\hline Manufacturing & 17.5 & -- & 413.0 & - & $8.2^{(0)}$ & 4.8 & $194.3^{(0)}$ & 114.9 \\
\hline (non-energy use) & $4.0^{(\mathrm{d})}$ & 1.7 & 94.2 & 40.1 & -- & 0.3 & - & 7.7 \\
\hline Total Industry & 20.4 & 18.9 & 480.7 & 445.9 & 8.5 & 5.6 & 199.9 & 130.8 \\
\hline $\begin{array}{l}\text { (a) Sources: JIEE } \\
\text { OECD-IEA 1987a. }\end{array}$ & & & $3 ;$ DOI & IA 1 & 9,1988 & 198 & $i$ and & \\
\hline (b) Totala may not & & & inden & dent & oundino & & & \\
\hline $\begin{array}{l}\text { (c) Includes non-e } \\
\text { (d) DOE-EIA (1989) }\end{array}$ & & $\begin{array}{l}\text { of } 1 \\
\text { afuel }\end{array}$ & se of & & & & & \\
\hline $\begin{array}{l}\text { for } 1985 \text {. DOE-EIA } \\
\text { manufacturing) as }\end{array}$ & $(1988)$ & & & & gy for & nonfu & use ( & jugt. \\
\hline
\end{tabular}

Table 5.4. U.S. Manufacturing Energy Consumption, $1985^{(a)}$

Industry

Food anci Rindred Products

Tobacco Manufactuxes

Textile Mill Products

Apparel and Other Textile Products

Lumber and Wood Products

Furniture and Fixtures

Paper and Allied Products

Printing and Publishing

Chemicals and Allied Products

Petroleum and Coal Products

Rubber and Miscellaneous Plaøtics Products

Leather and Leather Products

Stone, Clay, and Glass Products

Primary Metal Industries

Fabricated Metal Products.

Machinery, except Electrical

Electronic and Electronic Equipment

Transportation Equipment

Instruments and Related Products

Miscellaneous Manufacturing Establishments

Total Manufacturing

\begin{tabular}{rr}
$10^{12}$ Btu & \multicolumn{1}{c}{ MTOEg } \\
\hline 949 & 22.4 \\
19 & 0.4 \\
248 & 5.8 \\
31 & 0.7 \\
325 & 7.7 \\
48 & 1.1 \\
2211 & 52.1 \\
76 & 1.8 \\
3567 & 84.1 \\
5123 & 120.7 \\
213 & 5.0 \\
13 & 0.3 \\
895 & 21.1 \\
2626 & 61.9 \\
302 & 7.1 \\
240 & 5.7 \\
211 & 5.0 \\
321 & 7.6 \\
73 & 1.7 \\
31 & 0.7 \\
\hline 17,522 & 413.0
\end{tabular}

(a) SourCe: DOE-EIA 1988. 
The IEA does not report energy consumption for individual manufacturing industries (e.g., chemicals) for the U.S. Therefore, a detailed analysis of energy intensity by industry is performed using the MECS data (DOE-EIA 1988). Energy consumption for all purposes (including non-energy use of fuels) is used because this is compatible with data from Japanese domestic sources. A consistent set of definitions for the various manufacturing industries is developed in Section 5.2.3.

\subsection{Japanese Manufacturing Energy Consumption}

Table 5.5 presents energy consumption for the Japanese manufacturing sector. The classification of manufacturing industries has been collapsed somewhat from the original data source in order to be compatible with Table 5.4. The iron and steel and nonferrous metals industries have been combined into primary metals, and the rubber industry and plastics industry have also been combined.

As Table 5.5 shows, manufacturing energy consumption (194.3 MTOEs) as reported by MITI (1988) greatly exceeds energy consumption (114.5 MTOEs) reported by both the IEA (OECDEIA 1987a) and the JIEE (1989) domestic data source (all industry 121.7 MTOEs) reported in Table 2.1. The MITI data include fuels used as raw materials but exclude crude oil used in petroleum refining. As previcusly noted, the IEA lists nonfuel usage separately. This is also true of the JIEE data source, although it is not possible to disaggregate total nonfuel use of energy to any particular end-use sector (e.g., industrial). The analysis proceeds using both the IEA and MITI data because these two sources provide the greatest level of detail on an industry-by-industry basis. However, the MITI (1988) data are believed to be the most

Table 5.5. Japanese Manufacturing Energy Consumption, $1985^{(घ)}$

Induatry

Food and Kindred Products

Tobacco Manufactures

Textile Mill Products

Apparel and Other Textile Products

Lumber and Wood Pruducts

Furniture and Fixtures

Paper and Allied Producto

printing and Publishing

Petroleum and Coal Producta

Rubber and Miscellaneous Plastics Products

Leather and Leather Products

Stone, Clay, and Glass products

primary Metal Industries

Fabricated Metal Productg

Machinery, except Electrical

Electronic and Electronic Equipment

Transportation Equipment

Instruments and Related Products

Miscellaneous Manufacturing Establishments

Total Manufacturing
Chemicals and Allied Products

\begin{tabular}{rr}
$10^{3}$ rooe & MTOEs \\
3,986 & 3.5 \\
977 & 0.9 \\
2,648 & 2.3 \\
176 & 0.2 \\
244 & 0.2 \\
116 & 0.1 \\
10,885 & 52.1 \\
404 & 0.4 \\
49,168 & 43.2 \\
39,071 & 34.3 \\
2,150 & 1.9 \\
43 & 0.0 \\
13,236 & 11.6 \\
87,812 & 77.1 \\
1,493 & 1.3 \\
1,784 & 1.6 \\
2,881 & 2.5 \\
3,620 & 3.2 \\
246 & 0.2 \\
200 & 0.2 \\
\hline 221,140 & 194.3
\end{tabular}

(a) Source: MITI 1988

(b) $10^{3}$ kilolitres arude oil equivalent (kcoe) converted to MTOEs using 9,400

kcal/litre of crude oil and $10.7 \times 10^{6} \mathrm{kcal}$ per MPOE. Totals may not sum

becauge of independent rounding. 
comparable to the U.S. MECS (DOE-EIA 1988) data because both sources include nonfuel use of energy.

The IEA, like MITI, provides a breakdown of energy usage by individual industry. Table 5.6 includes the IEA (OECD-IEA 1987a) data as well as data taken from Table 5.5. The industry classifications were reduced from Table 5.5 using the table of correspondence (Table 5.2).

The IEA (OECD-IEA 1987a) and MITI (1988) data do not match well for any of the industries in Table 5.6. The greatest absolute difference appears to be in the chemicals and primary metal industries. (The largest percentage difference is in paper, pulp and printing.) Because the MITI (1988) data include fuels used as feedstocks in these industries, these differences may be largely explained by petrochemical feedstocks and coking coal. However, errors could have occurred in converting energy data from original units to MTOEs or kcals. To test this bypothesis, Table 5.7 presents data in original units from the MITI (1988) and IEA (OECD-IEA 1987b) sources.

Both the MITI (1988) and IEA (OECD-IEA 1987a) data sources have data for solid fuel (coal and coke) and electricity in original units. Coal and coke consumpliswi are reported in thousands of tonnes while electricity is reported in gigawatthours. As Table 5.7 shows, the data for solid fuel consumption and electricity consumption vary widely for several important industries.

\subsubsection{Comparative Energy Consumption}

The only recent industry-by-industry energy consumption data for the U.S. are the MECS data source (DOE-EIA 1988). Similar detailed data are not available from the IEA. The MECS data series, which includes nonfuel energy use, is used in order to be comparable with the MITI domestic data source for Japan.

The MITI (1988) data also allows a more detailed level of analysis than is possible with either the IEA (DECD-IEA 1987a) or JIEE (1989) data. Future studies may be able to resolve the percentage of fuel used as feedstocks in the MITI data, which will allow a comparative analysis with MECS (DOEEIA 1988) data without this usage. Differences in IEA and MITI reported data, as shown in Table 5.7, will still need to be resolved, however.

Table 5.8. compares energy usage by industry for the U.S. and Japan. These data are taken directly from Tables 5.4 and 5.5. Table 5.8 shows that

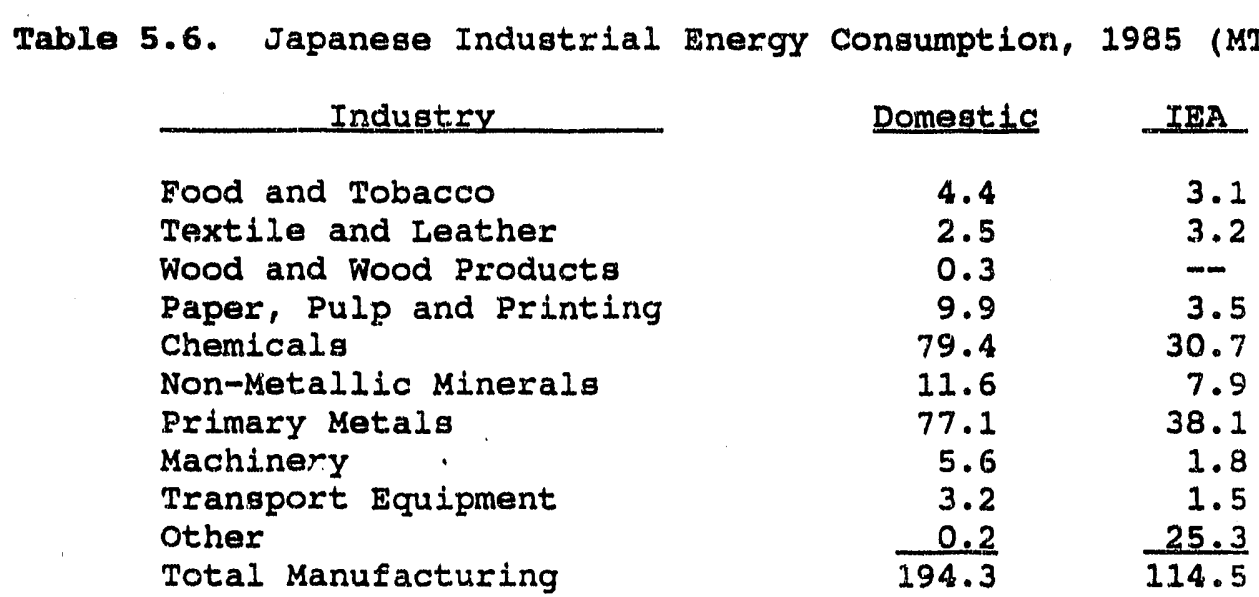

(a) Sources: MITI 1988, OECD-IEA 1987a.

(b) Totals may not sum because of independent rounding. 
Table 5.7. Japanese Industrial Energy Congumption by Fuel, $1985^{(a)}$

\begin{tabular}{|c|c|c|c|c|}
\hline \multirow[b]{2}{*}{ Iron and steel } & \multicolumn{2}{|c|}{$\begin{array}{l}\text { Coal and Coke } \\
\left(10^{3} \text { tonneg }\right) \\
\end{array}$} & \multicolumn{2}{|c|}{$\begin{array}{c}\text { Blectriolty } \\
\text { (qigawatt-hourg) }\end{array}$} \\
\hline & $\frac{\text { IEA }}{32,606}$ & $\frac{M I T I}{88,782}$ & $\frac{\text { IEA }}{70,438}$ & $\frac{\operatorname{MITI}}{67,574}$ \\
\hline Chemicalo & 1,406 & 41,520 & 46,193 & 63,127 \\
\hline Stone, Clay, and Glass & 8,479 & 8,465 & 16,569 & 20,418 \\
\hline Paper, Pulp, and Print & 755 & 1,044 & 23,993 & 27,826 \\
\hline Subtotal & 43,246 & 139,811 & 157,193 & 178,945 \\
\hline Other Manufacturing & 2,497 & 1,024 & 196,472 & 93,024 \\
\hline Total Manufacturing & 45,743 & 140,835 & 353,665 & 271,969 \\
\hline
\end{tabular}

(a) Sources: MITI 1988; OECD-IEA $1987 \mathrm{~b}$.

Table 5.8. Manufacturing Energy Congumption in the U.S. and Japan, 1985 (MTOEs) $^{(a)}$

Industry

Food and Rindred Products Tobacco Manufactures Textile Mill Producta Apparel and other Textile Product Lumber and Wood Products Furniture and Fixtures Paper and Allied Products Printing and publishing Chemicals and Allied Products Petroleum and coal Products Rubber and Miscellaneous Plastics products Leather and Leather Products Stone, Clay, and Glass Products Primary Metal Industries Fabricated Metal Products Machinery, except Electrical Electronic and Electronic Equip. Transportation Equipment Instruments and Related Products Miscellaneous Manufacturing Establishments Total Manufacturing

\begin{tabular}{rrr} 
U.S. & Japan & U.S.lJapan \\
22.4 & 3.5 & 6.4 \\
0.4 & 0.9 & 0.4 \\
5.8 & 2.3 & 2.5 \\
0.7 & 0.2 & 3.5 \\
7.7 & 0.2 & 38.5 \\
1.1 & 0.1 & 11.0 \\
52.1 & 9.6 & 5.4 \\
1.8 & 0.4 & 4.5 \\
84.1 & 43.2 & 2.0 \\
120.7 & 34.3 & 3.5 \\
5.0 & 1.9 & 2.6 \\
0.3 & 0.04 & 8.1 \\
21.1 & 11.1 & 1.8 \\
61.9 & 77.1 & 0.8 \\
7.1 & 1.3 & 5.5 \\
5.7 & 1.6 & 3.6 \\
5.0 & 2.5 & 2.0 \\
7.6 & 3.2 & 2.4 \\
1.7 & 0.2 & 8.5 \\
0.7 & 0.2 & 3.5 \\
\hline 413.0 & 194.3 & 2.1
\end{tabular}

(a) Sources: DOE-EIA 1988; MITI 1988. 
overall U.S. minufacturing energy consumption is about twice that of Japan.

The greatest differences in energy consumption are for the lumber and wood products and also furniture and fixtures industries, which probably reflects both the relative size of these industries (as will be shown in later sections) and the degree of vertical integration of these industries in the U.S. versus Japan. ${ }^{\left({ }^{(}\right)}$The U.S. also apparently consumes less energy in the primary metals industries.

\subsection{MANUFACTURING ACTIVITY}

To measure energy inivisity in the manufacturing sector, a scaling factor (denominator) is needed. An ideal measure of activity might be physical units such as tonnes of iron or steel, numbers of cars, or gallons of petrochemicals. For example, if the amount of energy required to produce steel and the total amount of steel produced were known., it would be rather straigitforward to divide the total energy cousumption by the tonnage of steel to arrive at the amount of energy required to produce a tonne of steel.

In some instances, data at this level of detail are available for some industries and selected products. Overall, however, the data are at a much higher level of agregation such as iron and steel; pulp, paper, and printing, and stone, clay, and glass (nonmetallic minerals). In such cases, such output measures as tonnes of stone, clay, and glass are sicauingless. Even if detailed breakout of quantities exist, data on energy consumption at this same level of detail do not.

An alternative measure of industrial activity is the value of the goods and servires produced. Manufacturing "value of output" is the dollar value of products produced by manufacturing industries, which consists of sales adjusted for inventory

(a) The U.S. lumber and wood products, and furniture and fixtures industries are fully integrated industries. That is, these industries include all antivities from the felling of trees to the production of a final product such as a chair. The Japanese, lacking sufficient timber as a natural resource, must import cut wood as a raw material. To the extent that felling trees and preparing lumber are more energy intensive than milling the fionl product, the U.S. industries will appear more energyintensive than their Japanese counterparts. changes. ${ }^{(b)}$ Value of output allows the production of dissimilar goods, such as square yards of glass or tonnes of crushed stone, to be aggregated together in terms of relative worth: the dollar value.

This measure of activity also has drawbacks. For instance, the relative value of a tonne of steel (primary metals) compared with a barrel of gasoline (chemical) will depend on raw material, capital, and labor costs in addition to energy costs (the amount of energy consumed times the cost of energy). The markets for these other inputs, as well as energy, may be distorted for a given industry from one country to the next, reducing the comparability of the value of output ineasure.

Table 5.9 shows the value of output by manufacturing industry for the U.S. and Japan. Once again, the Japanese industries have been collapsed somewhat in order to be comparable with U.S. definjtions. The Japanese data have been converted to U.S. dollars using the average 1985 exchange rate of 238.5 to 1 U.S. dollar.

\subsection{MANUFACTURING ENERGY INTENSITY}

Energy intensity in the manufacturing sector is calculated by dividing the energy consumption of each manufacturing industry by the value of output for that industry. ${ }^{(e)}$ This energy intensity value only accounts for direct energy use by that industry (i.e., the amount of energy consumed by that industry to produce a product). It does not include indirect energy use (the amount of energy embodied in an intermediate product purchased from industry " $\mathrm{A}$ " and used in production of the final product of industry "B") (Roop and Belzer 1987). Important to a more complete analysis would also be the energy inputs embodied in imports and exports of intermediate products for these industries (DOE 1989).

(b) Por the U.S, the value of ending inventory for 1984 was added to the 1985 product shipments. The 1985 ending inventories were then subtracted from this total, yielding 1985 production. For Japan, both the value of 1985 shipments and production were available. Value of production was used for Japan.

(c) The use of "value of output" data introduces problems with fluctuating exchange rates, as rated in the discussion of the $\mathrm{E} / \mathrm{GNP}$ ratio in Section 2.1. 
Table 5.9. Value of Industrial output, 1985

(billions of 1985 U.S. dollars) ${ }^{(a)}$

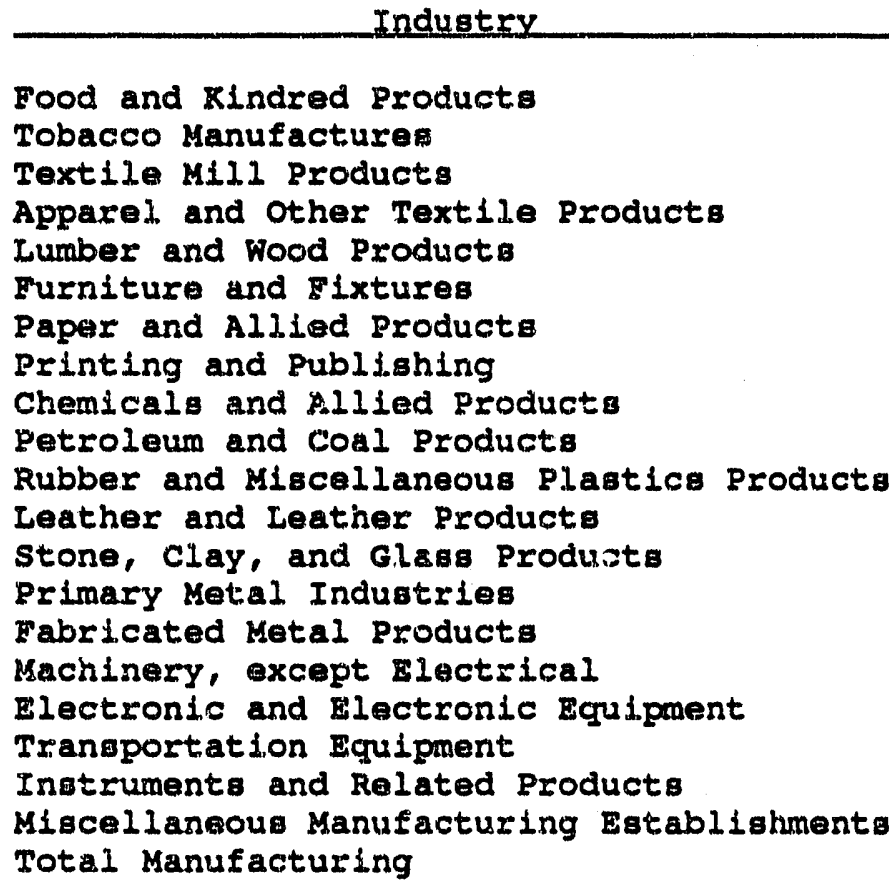

$\begin{array}{r}\text { U.S. } \\ \hline 301.9 \\ 19.1 \\ 53.8 \\ 57.2 \\ 54.2 \\ 31.4 \\ 93.6 \\ 111.9 \\ 197.7 \\ 179.6 \\ 71.1 \\ 8.7 \\ 55.2 \\ 112.8 \\ 140.2 \\ 217.9 \\ 192.7 \\ 299.9 \\ 60.8 \\ 26.7 \\ \hline 2286.5\end{array}$

Iapan

86.3

36.0

34.1

15.3

16.9

11.9

31.0

37.5

86.2

53.9

46.4

4.3

37,1

101.4

54.9

102.3

172.2

151.4

18.6

17.0

1114.8
U.S. / Japan

3.5

0.5

1.6

3.7

3.2

2.6

3.0

3.0

2.3

3.3

1.5

2.0

1.5

1.1

2.6

2.1

1.1

2.0

3.3

1.6

(a) Sources: MITI 1988; DOC 1987b, 1986.

Table 5.10 shows direct energy intensity of U.S. and Japanese manufacturing industries. As the table shows, most U.S. industries are more energyintensive than their Japanese counterparts. However, overall, energy intensity in the U.S. (180.6) manufacturing industry compares favorably with that of Japan (174.3). This illustrates the importance of "industry mix" to the analysis of manufacturing energy intensity.

The U.S. lumber and wood products industry is 11.1 times as energy-intensive as its Japanese counterpart. The U.S. primary metals industry, on the other hand, appears to be less energy-intensive than the Japanese. These two extremes can probably be accounted for in part by product mix. As noted before, the U.S. timber industry is fully integrated (e.g., trees are felled, sawn, and made into tinal products). The Japanese, on the other hand, do not have a forest resource and must import lumber that has at least been partially milled. The primary metals industry, on the other hand, consists of iron and steel, aluminum, copper, and other metals, as well as various stages of milling and finishing.

A closer comparison of primary metals shows that crude steel production in Japan in 1986 was $98,513,000$ tonnes, while raw aluminum production was only 140,000 tonnes (MITI 1988). The U.S. produced 74,032,000 tonnes of raw steel in 1986 and $3,036,000$ tonnes of primary aluminum (DOC 1989). These totals show that raw steel production, which is relatively more energy-intensive than primary aluminum production (especially when coking coal is in. cluded), comprises a far larger proportion of the primary metals industry in Japan than in the U.S. This would tend to make the U.S. primary metals industry less energy-intensive than its Japanese counterpart.

Table 5.11 also has energy intensity data for the manufacturing sectors of Japan and the U.S. However, in this case both domestic and IEA data are used for Japanese energy consumption. The 


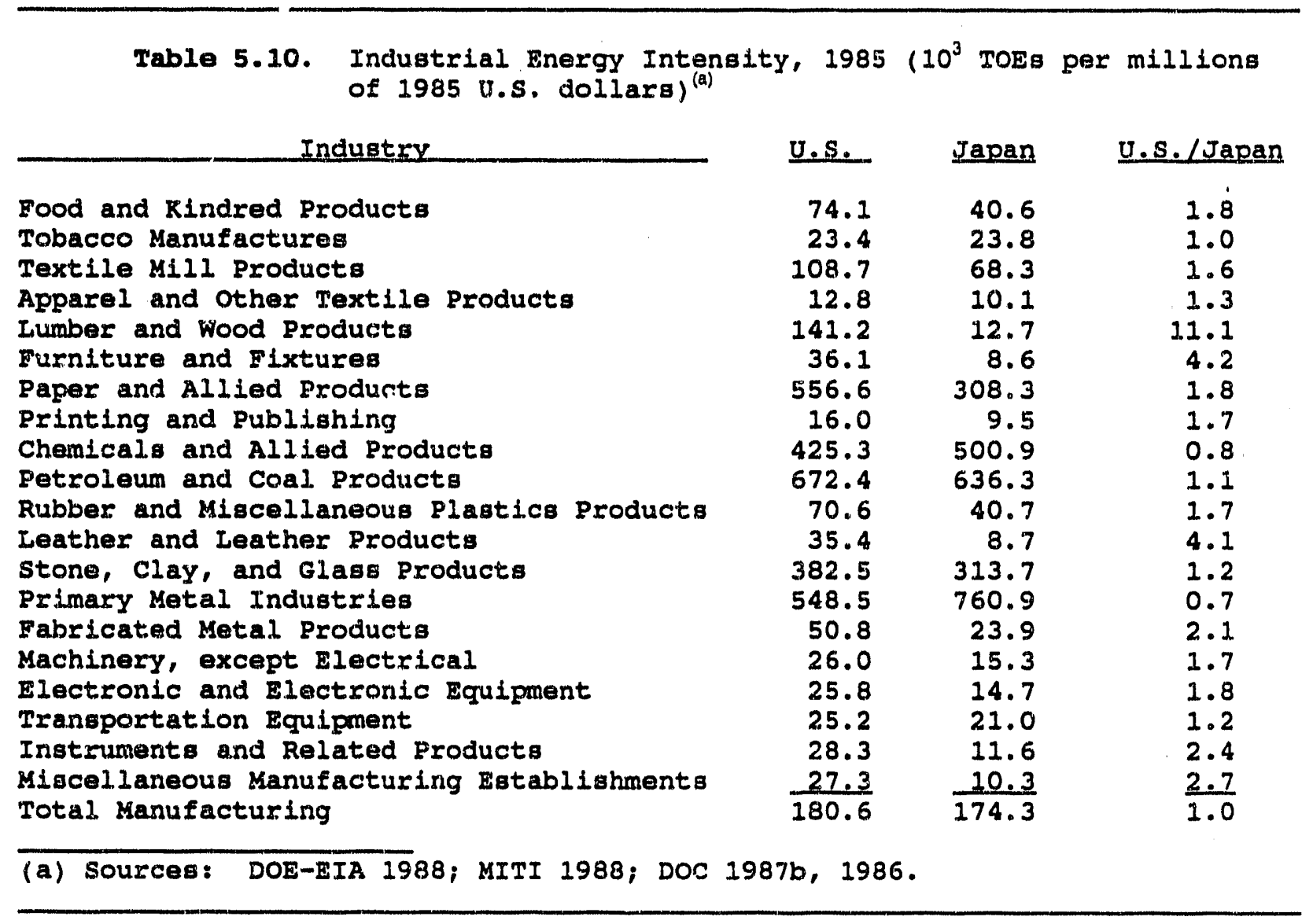

Table 5.11. Industrial Energy Intensity Using All Data Sources, 1985 $\left(10^{3}\right.$ TOEs per millions of 1985 U.S. dollars) ${ }^{(a)}$

\begin{tabular}{|c|c|c|c|}
\hline & \multirow{2}{*}{$\frac{\text { U.S. }}{\text { MECS }}$} & \multicolumn{2}{|c|}{ Japan } \\
\hline & & Dom. & IEA \\
\hline Food and Tobacco & 71.1 & 35.6 & 25.0 \\
\hline Textile and Leather & 57.5 & 46.9 & 59.2 \\
\hline Wood and Wood Products & 1.02 .7 & 11.0 & -- \\
\hline Paper, Pulp and Printing & 262.3 & 144.8 & 50.7 \\
\hline Chemicala & 468.0 & 425.5 & 164.6 \\
\hline Non-Metallic Kinerals & 382.5 & 313.7 & 211.8 \\
\hline Primary Metal. & 548.5 & 760.9 & 376.0 \\
\hline Machinery. & 31.8 & 16.2 & 5.2 \\
\hline Transport Equipment & 25.2 & 21.0 & 9.7 \\
\hline Other & 27.3 & 10.3 & 1483.3 \\
\hline Total Manufacturing & 180.6 & 174.3 & 103.1 \\
\hline
\end{tabular}

(a) Sources: DOE-EIA 1988; MITI 1988; DOC 1987b, 1986; OECD-IEA $1987 \mathrm{a}$. 
industry detail has been reduced in order to be compatible with all three classification schemes (SIC, JSIC, and ISIC).

Table 5.11 shows that industrial energy intensity varies markedly for Japan, depending on whether the doinestic or IEA data source is used for energy consumption. If IEA data are used, all U.S. manufacturing industries except one (textile and leather) are more energy-intensive than Japanese industries, at least at this level of aggregation. Overall, either the U.S. minufacturing sector is about as energyintensive as the Japanese (using domestic sources) or is almost twice as intensive as the Japanese (using IEA data). However, given that the Japanese domestic data and U.S. MECS data are closer in definition than IEA data (the IEA data shown here do not include nonfuel use of energy, which is in. cluded in the MECS and MTTI data), it appears that the U.S. is about equal to Japan in energy intensity for the manufacturing sector taken as a whole. The high degree of energy intensity for "other" industries for Japan arises from the fact that the IEA "non-specified" category contains $6 \%$ of total manufacturing energy consumption, while only $1.5 \%$ of the value of output is designated for this category.

By using value of output as the denominator to this energy intensity measure, the analysis becomes sensitive to both exchange rates, and if chosen, the base year to which to deflate the value of output data. For instance, if the data for the value of manufactured goods were deflated to 1980 U.S. dollars, manufacturing energy intensity in Japan would fall approximately $20 \%$ for each industry. This is equal to the relative difference in inflation rates between the two countries from 1980 to 1985. likewise, if a more recent exchange rate is used, say $140 \%$ to the dollar, manufacturing energy intensity in Japan falls another $65 \%$. The combined effect of deflating the series and using a more recent exchange rate would be to reduce overall Japanese manufacturing energy intensity to about one-half that of the U.S. using the MECS (DOE-EIA 1988) and MITI (1988) data. 


\subsection{CONCLUSIONS AND RECOMMENDATIONS}

\subsection{CONCLUSIONS}

The aggregate measure used for comparisons of energy intensity, the E/GDP ratio, shows the U.S. to be about twice as energy-intensive as Japan. When adjustments are made for certain differences between the U.S. and Japan, the U.S. compares more favorably. For instance, the U.S. consumes about twice the amount of energy per square meter of residential living space per person, if allowances are made for climate. While the difference is large, this is a substantial improvement over the seven- to eight-fold difference in residential energy consumption. Likewise, several different U.S. commercial building types appear to be approximately equivalent, or even less energy-intensive than their Japanese counterparts if adjustments are made for climate and floorspace.

The U.S. consumes about eight times as much energy for passenger transportation as Japan. At least part of this difference can be explained by the fact that the average travel per person in the U.S. is about three times that of Japan. However, the U.S. is twice as energy-intensive in passenger movement than Japan. That is, the U.S. consumes about twice as much energy moving one passenger one kilometer as Japan. The reason for this appears to be the overwhelming use of the private automobile in the U.S. versus mass transit in Japan. If allowances are made for this travel mode choice; that is, if the Japanese were to travel more "like" people in the U.S., Japanese passenger travel energy intensity would rise to the level of the U.S.

About half the energy is required for freight movement (when normalized for distance and vehicle capacity) in the U.S. versus Japan. The reason for this appears to be the more predominant use in the U.S. of rail transport, which is less energyintensive than alternative forms of freight movement. Japan, on the other hand, relies more heavily on ship transport, which is relatively more energyintensive. Finally, U.S airplanes, trucks, and trains are less energy-intensive per vehicle-kilometer traveled than their Japanese counterparts, while U.S. cars and buses are more energy-intensive.
The U.S. manufacturing sector, on the whole, is about on par with Japan in terms of the amount of energy consumed in producing a dollar's worth of goods. However, this result is highly dependent on the exchange rate employed and whether current or constant dollars (deflated to some base year) are used in the analysis. If a more recent exchange rate is used, Japanese manufacturing energy intensity falls by about $65 \%$. If the data are deflated to 1980 constant dollars, Japanese energy intensity decreases by about another $20 \%$.

The measures developed here show the U.S. to compare more favorably with Japan in terms of energy intensity than the aggregate E/GDP ratio indicates. These measures highlight that some portion of the difference in energy consumption between the U.S. and Japan can be explained by factors other than energy efficiency. These factors can be thought of in terms of living standards and customs.

For instance, U.S. residences consume more energy per household than the Japanese, even after allowing for differences in climate. However, because Japanese homes are smaller and households are larger, energy consumed per square meter of living space per person is smaller. Energy consumption can be reduced in households by installing more energy-efficient equipment and by using super in. sulating techniques, but an alternative certainly is movement towards smaller homes in warmer climates in the U.S.

Likewise, while more efficient cars are availabie, the U.S. could reduce energy intensity in passenger travel further if the U.S were to forego cars in favor of bus and rail travel. However, given that the average rate of travel per person in the U.S. is three times that of Japan, passenger travel would also have to be reduced in order to bring transportation energy consumption more in line with the Japanese. In the U.S., both car ownership and the freedom to travel in those cars are associated with a higher standard of living. 


\subsection{RECOMMENDATIONS}

A number of data problems still need to be resolved. These problems relate primarily to the discrepancy between IEA and Japanese domestic data sources for manufacturiug energy consumption. However, there is not good correspondence between U.S. and Japanese domestic data and the IEA international data for other sectors as well. These differences need to be understood and resolved if the IEA data are to be deemed reliable.

A more comprehensive analysis of the residential and commercial sector is required. In this study, some adjustments were made for climate, and in the case of the residential sector, living space per person. However, climate is just one determinant of energy consumption in these two sectors. More information is needed on non-space beating uses of energy, such as water heating and refrigeration in residences and lighting in commercial buildings.

Remaining issues in the transportation sector are more subtle. For instance, school bus transportation data were used for the U.S., but it is unclear whether the Japanese data also included transport of school children. Also, there appears to be a severe incompatibility of data for train-kilometers traveled, which makes Japanese rail transport seem far less energy efficient than can reasonably assumed to be true.

For the industrial sector, the measure developed in this study for energy intensity in manufacturing is highly sensitive both to exchange rates and to whether current or constant dollars are used in the analysis. This is not an argument for using one exchange rate or another, or for using current dollars versus dollars deflated to a selected base year. Disagreement as to the appropriate exchange rate and base year for deflation is expected. This merely shows the sensitivity of this measure, as well as the aggregate $E / G D P$ ratio, to the method used to transform the financial data for purposes of comparison. Physical comparisons, such as energy consumed per tonne of stone, clay, and/or glass, are difficult to construct and use. The comparisons are too aggregate for an industry grouping and do not provide a meaningful comparison or are too numerous if a fine level of detail is pursued (such as energy consumed per tonne of stainless steel, etc.), even if energy consumption data were availabie for all industries at this level of detail. 


\subsection{REFERENCES}

Annols, G. R., K. B. Howard, A. K. Nicholls, and T. D. Guerra, eds. 1988. Residential and Commercial Buildings Data Book, Third Edition. PNL-6454, Pacific Northwest Laboratory, Richland, Washington.

Anzia, Y., et al. 1989. Japan 1989: An International Comparison. Tokyo.

Boyd, G., J. F. McDonald, M. Ross, and D. A. Hanson, eds. 1987. "Separating the Changing Composition of U.S. Manufacturing Production from Energy Efficiency Improvements: A Divisia Index Approach." The Energy Journal 8(2).

Chandler, W. U. 1988. "Assessing Carbon Emission Control Strategies: The Case of China." Climatic Change 13:241-265.

Climate Dictionary. See Kicho No Jiten.

Darmstadter, J., J. Dunkerley, and J. Alterman. 1977. How Industrial Societies Use Energy: $A$ Comparative Analysis. Resources for the Future, Johns Hopkius University Press, Baltimore, Maryland.

DOC. See U.S. Department of Commerce.

DOE. See U.S. Department of Energy.

DOT. See U.S. Department of Transportation.

Fraakena, F. 1977. Energy Intensity: A Selected Annotated Bibliography. Michigan State University, Department of Sociology, Council of Planning Librarians, Exchange Bibliography \#1306, Ann Arbor, Michigan.

Geller, H. 1989. U.S. Energy Demand: Back to Robust Growth? American Council for and EnergyEfficient Economy, Washington, D.C.

International Monetary Fund (IMF). 1986. International Financial Statistics, Yearbook, 1986.

Washington, D.C.
Japan Economic Planning Agency. 1987. 1987 New Social Indicators: Result of 1987 Calculation Based on NSI. Social Policy Bureau, Tokyo.

Japan Economic Planning Agency. 1988. Annual Report on the National Life For Fiscal 1987: The Higher Yen and Forming of Affluent Infrastructures. Tokyo.

Japan Economic Planning Agency. 1989. Economic Survey of Japan, 1987-1988. Tokyo.

Japan Institute of Energy Economics (JIEE). 1987. Survey on Energy Consumption in Commercial Sector. Tokyo.

Japan Institute of Energy Economics (JIEE). 1989. Enerugi Bransu Hyo (Energy Balance Tables).

Tokyo.

Japan Ministry of Construction. 1987. White Paper on Construction 1987. Research Institute of Construction and Economy, Tokyo.

Japan Ministry of International Trade and Industry (MITI). 1988. Statistic on Japanese Industries (1988). Research and Statistics Department, Tokyo.

Japan Ministry of 'Transport. 1987. Summary of Energy Consumed Related to Transportation. Tokyo.

Japan Ministry of Transport. 1988. Annual Report on The Transport Economy, Summary (Fiscal 1987). Research and Data Processing Department Transport Policy Bureau, Tokyo.

Japan Statistics Bureau. 1986. Housing of Japan: Summary of the Results of 1983 Housing Survey of Japan. Management and Coordination Agency, Tokyo.

Japan Statistics Bureau. 1988. Japan Statistical Yearbook, 1988. Management and Coordination Agency, Tokyo. 
Kellogg, W. W. and R. Schware. 1981. Climatic Change and Society: Consequences of Increasing Atmospheric Carbon Change. Westview Press, Boulder, Colorado.

Ketoff, A, et al. 1987. Evolution of Residential Energy Demand in OECD Countries, Part One: 1970-1984 Data Base. LBL-22267, Lawrence Berkley Laboratory, Applied Science Division, International Energy Studies, Berkeley, California.

Kicho No Jiten (Climate Dictionary). 1986. Degree Day Data for 80 Locations in Japan. Heibon Publishing, Tokyo.

Kraft, J. and A. Kraft. 1978. "On the Relationship Between Energy and GNP." The Joumal of Energy and Development, pp.401-03.

MITI. See Japan Ministry of Intern ttional Trade and Industry.

National Oceanic and Atmospheric Administration (NOAA). 1987a. State, Regional, and National Monthly and Seasonal, Cooling Degree Days: Weighted by Population, January 1931-December 1986. Historical Climatology Series 5-2, National Climatic Data Center, Asheville, North Carolina.

National Oceanic and Atmospheric Administration (NOAA). 1987b. State, Regional, and National Monthly and Seasonal, Heating Degree Days: Weighted by Population, January 1931- December 1986, Historical Climatology Series 5-1, National Climatic Data Center, Asheville, North Carolina.

Organization for Economic Cooperation and Development (OECD). 1987. Industrial Structure Statistics 1985. Paris.

Organization for Economic Cooperation and Development (OECD). 1988a. Main Economic Indicators. Department of Economics and Statistics, Paris.

Organization for Economic Cooperation and Development (OECD). 1988b. National Accounts: Main Aggregates. Volume I, Department of Economics and Statistics, 1960-1986, Paris.
Organization for Economic Cooperation and Development - International Energy Agency (OECDIEA). 1987a. Energy Balancss of OECD Countries 1970-1985: and Main Series from 1960, Paris.

Organization for Economic Cooperation and Development - International Energy Agency (OECD. IEA). 1987b. Energy Statistics 1970-1985: and Main Series from 1960, Volume II, Paris.

Organization for Economic Cooperation and Development - International Energy Agency (OECDIEA). 1988. Energy Policies and Programmes of IEA Countries: 1987 Review. Paris.

Podolak, M. 1988. "Appropriate Comparisons of International Energy Data." In Monthly Macro Update, U.S. Department of Energy, Washington, D.C.

Roop, J. M. and D. B. Belzer. 1987. Changers in the Structure of the U.S. Economy: An Input Output Analysis. PNL-SA-35961, Pacific Northwest Laboratory, Richland, Washington.

Ruggeri, G. C. 1983. "A Note on the Energy-GNP Relationship in Canada, 1961-1980." The Joumal of Energy and Development.

Schipper, L., and A. Ketoff. 1983. "Home Energy Use in Nine OECD Countries, 1960-1980." Energy Policy.

Schipper, L., and A. Ketoff. 1985. "Residential Energy Use in the OECD." The Energy Journal 6(4).

United Nations (UN). 1988. Monthly Bulletin of Statistics, Statistical Office, Volume XLII, No. 10, New York.

United Nations - Food and Agricultural Organization (UN-FAO). 1986. FAO Production Yearbook, Volume 40, New York.

U.S. Department of Commerce (DOC). 1982. "Fuels and Electric Energy Consumed, Industry Groups and Industries." In 1980 Annual Survey of Manufacturers (ASM). Bureau of tue Census, M80(AS)-4.1, Washington, D.C. 
U.S. Department of Commerce. 1985. 1982 Census of Manufacturers and Census of Mineral Industries. Numerical List of Manufactured and Mineral Products. MC82-R-1, U.S. Department of Commerce, Bureau of the Census, Washington, D.C.

U.S. Department of Commerce (DOC). 1986.

"Value of Product Shipments." In 1984 Annual Sur. vey of Manufacturers (ASM). Bureau of the Census, M84(AS)-2, Washington, D.C.

U.S. Department of Commerce (DOC). 1987a. Statistical Abstract of the United Staies, 1988.

Bureau of the Census, 108th Edition, Washington, D.C.

U,S. Department of Commerce (DOC). $1987 \mathrm{~b}$. "Value of Product Shipments." In 1985 Annual Survey of Manufacturers (ASM), Bureau of the Census, M85(AS)-2, Washington, D.C.

U.S. Department of Commerce (DOC). 1989. Survey of Current Business. Bureau of Economic Analysis, Volume 69, No. 6, Washington, D.C.

U.S. Department of Energy (DOE). 1985. Energy Intensities for the U.S. Economy - 1977.

DOE/CE/27436--T1, Washington, D.C.

U.S. Department on Energy (DOE). 1989. Enengy's Role in International Trade: Structural Change and Competitiveness. Office of Policy, Planning, and Analysis, DOE/PE-0090, Washington, D.C.

U.S. Department of Energy - Energy Information Administration (DOE-EIA). 1986. Nonresidential Buildings Energy Consumption Survey (NBECS): Commercial Buildings Consumption and Expenditures 1983. DOE/ELA-0318(83), Washington, D.C.
U.S. Department of Energy - Energy Information Administration (DOE-EIA). 1987a. Residential Energy Consumption Survey (RECS): Consumption and Expenditures, April 1984 through March 1985. DOE/EIA-0321/1(84), Washington, D.C.

U.S. Department on Energy - Energy Information Administration (DOE-EIA). 1987b. State Energy Data Report, Consumption Estimates, 1960-1985. DOE/EIA-0214(85), Washington, D.C.

U.S. Department of Energy - Energy Information Administration (DOE-EIA). 1988. Manufacturing Energy Consumption Survey (MECS): Consumption of Energy 1985. DOE/ELA-0512(85), Washington, D.C.

U.S. Department of Energy - Energy Information Administration (DOE-EIA). 1989. Annual Energy Review, 1988. DOE/EIA-0384(88), Washington, D.C.

U.S. Department of Transportation (DOT). 1987. National Transportation Statistics, Annual Report, 1987, Washington, D.C.

Yu, E. S., and C. Jai-Young. 1985. "The Casual Relationship Betveen Energy and GNP: An International Comparison." The Journal of Energy and Development 10(2). 

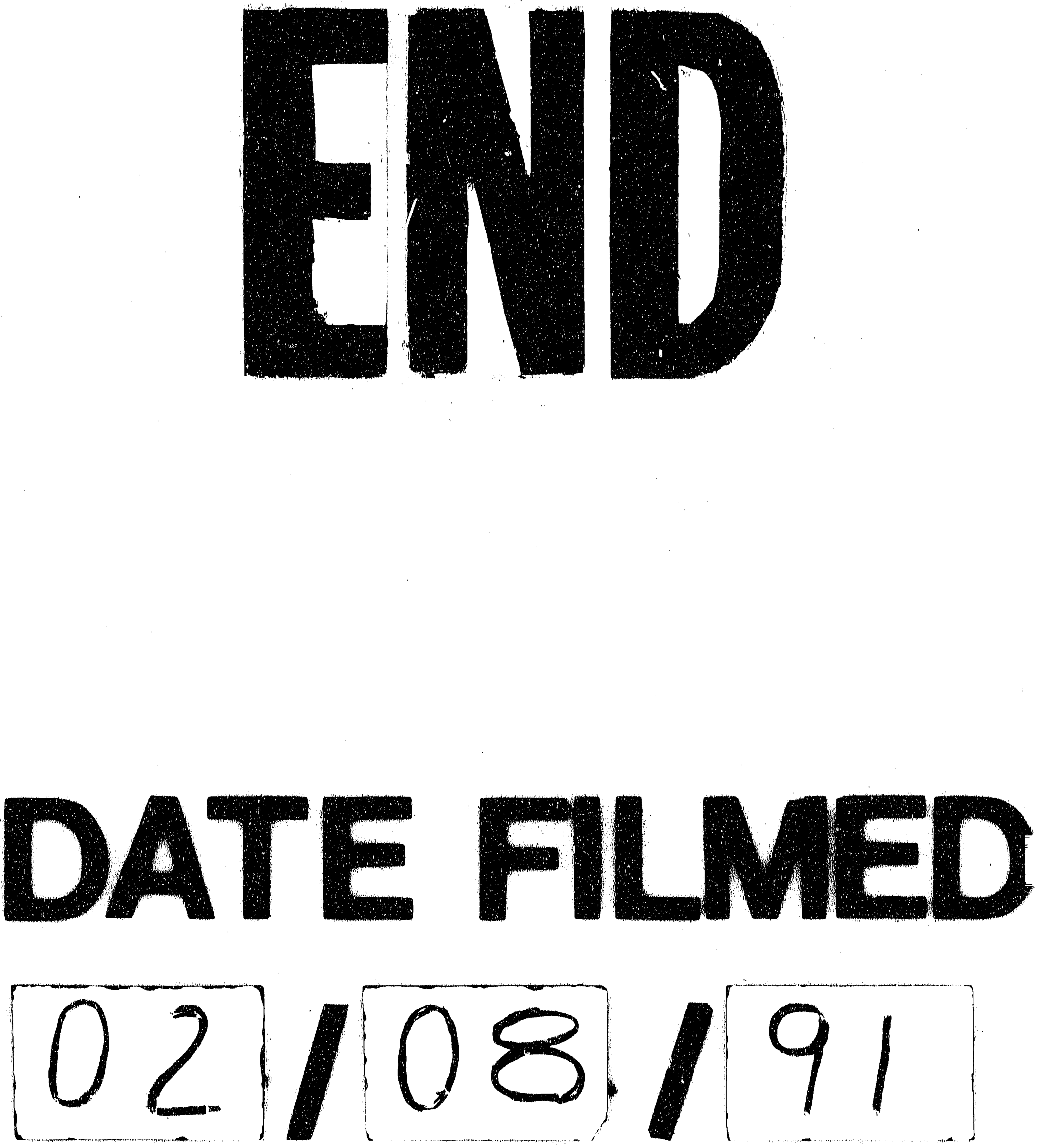
$=$ 